\title{
Research in business service purchasing: current status and directions for the future
}

\author{
Erik Hofmann $^{1}$ D . Joël Henri Brunner ${ }^{1}$ • Elmar Holschbach ${ }^{2}$
}

Received: 11 April 2019 / Accepted: 16 August 2019 / Published online: 24 August 2019

(C) Springer Nature Switzerland AG 2019

\begin{abstract}
This paper provides a systematic literature review and a future research agenda on the topic of purchasing of business services (BuSe). BuSe purchasing has increasingly gained in importance during the past years. It has established itself as a relevant sub-discipline in purchasing and supply management. This "state of research" paper identifies the main authors, relevant topics and practical implications as well as upcoming developments. For this purpose, 118 publications were collected and analyzed. While early research on BuSe purchasing was strongly influenced by the American marketing literature, more recent papers are also published by European authors and institutions coming from the core of the purchasing and supply management discipline. In general, the literature lacks in theoretical foundation and longitudinal methods while assuming high generalizability. Based on the analyses and additional discussions within the research team, directions for future research are identified at a political, economic, social and technological (PEST) level. The following trends for service purchasing were elaborated: (1) "Glocalisation" and nearshoring, (2) sustainability and corporate social responsibility (CSR), (3) internal and external collaboration, (4) value-driven contract and payment systems, (5) hybrid products and servitization, and (6) big data analytics, artificial intelligence and process automation.
\end{abstract}

Keywords Systematic literature review · Buying · Procurement - Sourcing · Machine learning $\cdot$ Blockchain $\cdot$ Performance based contracting $\cdot$ Digitalization · Industry 4.0

Erik Hofmann

erik.hofmann@unisg.ch

Joël Henri Brunner

joel.brunner@bluewin.ch

Elmar Holschbach

holschbach.elmar@fh-swf.de

1 Institute of Supply Chain Management, University of St. Gallen, Dufourstrasse 40a, 9000 St. Gallen, Switzerland

2 Department of Engineering and Business Administration, South Westphalia University of Applied Sciences, Lindenstrasse 53, 59872 Meschede, Germany 
JEL Classification M10 $\cdot$ L14 $\cdot$ L24 $\cdot$ L80

\section{Introduction}

"Services generate more than two-thirds of global gross domestic product (GDP), attract over three-quarters of foreign direct investment (FDI) in advanced economies, employ the most workers, and create most new jobs globally" (Nordås et al. 2017 , p. 9). Following this statement, the global economy can be regarded as service driven. In this context, firms are not only the producers of services, but also their consumers. This is due to increased levels of specialization which implies that companies outsource their non-core functions and create less value-added services themselves. Additionally, servitization and digitalization of business processes transform traditional product-based firms to service providers. The share of externally sourced business services (BuSe) has increased over the last decades and is estimated to account for at least 20-30\% of total spend (Hänsel and Hofmann 2017). In the study at hand we define BuSe as services, which are delivered by firms or organizations and bought by other firms or organizations, which makes BuSe distinct from organizations concerned with consumer services (Holschbach 2013; Axelsson and Wynstra 2002; van der Valk and Rozemeijer 2009).

Despite this significance, knowledge about purchasing of BuSe in practice and academia is still limited (Bals et al. 2009; Ellram and Tate 2015; Roth et al. 2004). This may be due to the continued focus on purchasing of goods. In addition, purchasing of BuSe is considered more difficult than purchasing of goods by practitioners (Fitzsimmons et al. 1998a; Stock and Zinszer 1987; van der Valk and Rozemeijer 2009). Grönroos (2009, p. 357) argues that this may result from the fact that producers of services are "value co-creators jointly with their customers". Axelsson and Wynstra (2002) stress that the inherent characteristics of services make certain steps of the purchasing process for BuSe more difficult, important or just plain different (see also Wynstra et al. 2018).This was already noted by Wittreich (1966, p. 153), who remarked that the rich literature written in the area of goods purchasing is not applicable for buying services due to the different characteristics of services. Van der Valk (2008, p. 301) summarizes that existing knowledge in the field of purchasing has mostly been aimed at buying goods and applying it to services is "inadequate". Additionally, the existing research in BuSe purchasing is spread over various research areas and lacks clarity in terminology and concepts.

Thus, the state of the knowledge does not match the importance of the subject. In order to collect and recap the current state of knowledge, this paper provides a systematic review of the existing literature in the area of service purchasing. As Boote and Beile (2005, p. 3) explain "a researcher cannot perform significant research without first understanding the literature in the field". A previous literature review on this topic was published by Nordin and Agndal (2008, p. 1). The authors' goal was to "review, analyze and categorize empirical research" on purchasing of BuSe in the private sector. Their publication provides a first broad overview of the literature on BuSe. However, it lacks in transparency and reproducibility as the authors do not reveal how the keywords were devised and what combinations of keywords were used in the search. 
Furthermore, their collected body of literature is more than 10 years old now, which in itself justifies a new analysis of the current status of research (Short 2009).

Despite the advances in research on purchasing of BuSe in the last decade, there is still much room for improvements. Shifting the focus from backward- to forwardlooking, an agenda for potential future research is still missing. Such an agenda can be developed on basis of the criticism on the current status of research, which serves as a "a firm foundation for advancing knowledge" in the particular field (Webster and Watson 2002, p. xiii). Thus, future research in BuSe purchasing should not be restricted on theoretical and methodological issues only but should also focus on new developments and relevant content in practice.

Our review tries to answer three research questions, which are guided by three ideas. First, we want to better understand what the current state in this field i.e. what topics, authors and networks make up the research of BuSe. Second, we aim at finding theoretical and methodological gaps in the existing literature to assess the strengths and potential weaknesses of the research field. Third, we would like to identify in which direction the service purchasing research field should go i.e. what new topics should be addressed by future research:

- $R Q 1$ What is he current state of research on business service purchasing?

- $R Q 2$ What are theoretical and methodological gaps in the field of business service purchasing?

- RQ3 What are topics that need to be addressed in the future by business service purchasing?

As the first two research questions deal with the status quo of research in the area of purchasing of BuSe, they will be answered using the method of a systematic literature review. The third research question, by contrast, is related to future topics of BuSe purchasing which may not yet be reflected in the literature. Therefore, the literature review in combination with external studies were used as a basis for further discussion within the research team.

In the literature, only studies can be found which either include conceptual paper or draw on empirical paper, as in the case of Nordin and Agndal (2008), for example. Therefore, both conceptual and empirical papers were consulted to enhance the quality of the research. Furthermore, our review does not exclude any business sectors, industries or countries. In order to limit the scope, only scientific publications in English at a certain quality level were taken into consideration.

The paper is organized as follows: The next section further explains the method of our review. The third and the fourth section analyze the body of literature on bibliometric and content aspects. Based on the previous analysis, a future agenda along the PEST levels is developed in Sect. 5. The paper ends with a conclusion in Sect. 6. 


\section{Method}

This paper provides a systematic review of the literature on BuSe purchasing. Systematic in this context means a "structured approach to identifying, evaluation and synthesizing research", while also providing a "reproducible process" for future research (vom Brocke et al. 2015, pp. 9-10). Additionally, the overarching idea is to counteract "bias by making explicit the values and assumptions" that went into the review process (Tranfield and Denyer 2003, p. 208). To achieve this, we clarify how the body of literature was collected. The procedure applied is informed by the publications of vom Brocke et al. (2015), Tranfield and Denyer (2003) and expanded by ideas from Provost and Fawcett (2013). It was conducted in June 2018.

\subsection{Keyword definition}

In a first step, we aimed at identifying keywords which cover the field of BuSe purchasing comprehensively and represent the content of most papers in this field. This paper refers to BuSe as services, which are delivered by firms or organizations and bought by other firms or organizations (Axelsson and Wynstra 2002). Examples for BuSe are marketing, information technology, facility management or consultancy services (van der Valk and Rozemeijer 2009). In order to achieve this, an initial set of literature, which was deemed relevant in the field of BuSe purchasing, was screened by the researchers. The screening was based on a set of literature, which spread over different forms of publications (papers, books and conference papers), established and upcoming authors and new and old articles. The collection included six publications by Day and Barksdale (1994), Axelsson and Wynstra (2002), Agndal et al. (2007), Van Weele (2005), van der Valk (2008) and Hänsel and Hofmann (2016).

It became clear that there is a plethora of words used to express similar concepts. Axelsson and Wynstra (2002, p. 19), for example, use "purchasing, procurement and buying interchangeably [...] for reasons of variety". Van der Valk (2008, p. 301) mainly uses "procurement", Agndal et al. (2007, p. 188) focus on the term "sourcing" and Hänsel and Hofmann (2016, p. 2) speak of "purchasing". Additionally, the authors often did not state if their publications are focused either on the $\mathrm{B} 2 \mathrm{~B}$ or the $\mathrm{B} 2 \mathrm{C}$ sector. Therefore, we excluded both terms from our list of initial keywords.

To help find the appropriate keywords a simple "bag of words" approach was used from the data mining literature. The approach "[...] treats every word in a document as a potentially important keyword" (Provost and Fawcett 2013, p. 250). Then, the frequency of a word in the document is counted. The approach was refined by calculating, additionally to the frequency, the inverse document frequency (IDF) for each potential keyword. The IDF returns how special a term in a corpus of literature is. A corpus of literature is defined as a multitude of documents.

$$
(I D F)(\text { term })=1+\log \left[\frac{\text { Total number of documents }}{\text { Number of documents containing }(\text { term })}\right]
$$




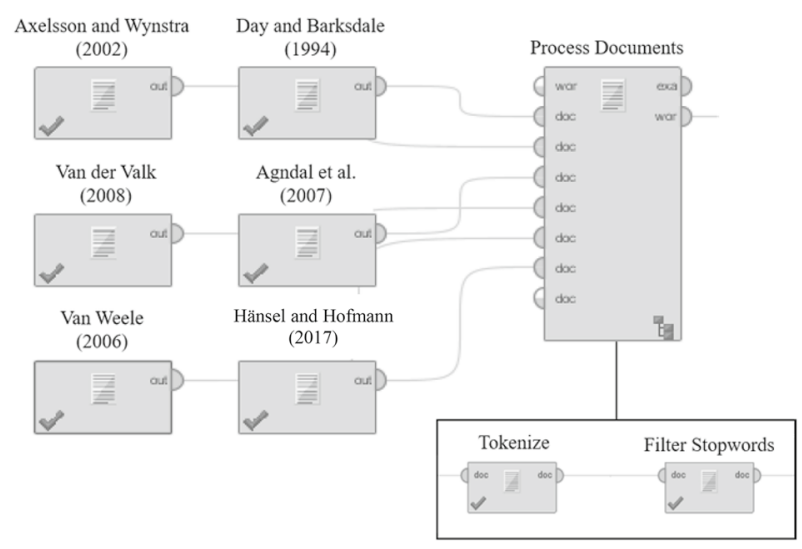

Fig. 1 Bag of words approach build in Rapidminer

Table 1 Bag of words-approach top-20 keywords

\begin{tabular}{lllcllll}
\hline Keywords & Rank & Keywords & Rank & Keywords & Rank & Keywords & Rank \\
\hline Sourcing & 1 & Process & 6 & Criteria & 11 & Purchase & 16 \\
Evaluation & 2 & Research & 7 & Customers & 12 & Industrial & 17 \\
Buying & 3 & Interaction & 8 & Quality & 13 & Involved & 18 \\
Company & 4 & Customer & 9 & Firm & 14 & Supply & 19 \\
Supplier & 5 & Performance & 10 & Processes & 15 & Requirements & 20 \\
\hline
\end{tabular}

In our case the six documents from the initial set of literature were fully imported into Rapidminer ${ }^{1}$ to identify the terms ${ }^{2}$ which are most relevant for these six documents. The "Filter Stopwords"-operator was used to exclude the most common English words (for example, 'and', 'or', 'is' etc.) so that only specific words of these documents were counted (Fig. 1).

In the resulting list the absolute frequency of a keyword was divided by the $I D F$. Thus, words were favored which not only appeared frequently but also in multiple documents of the corpus. This resulted in the following terms (Table 1):

The terms were not yet "stemmed", so terms such as customer and customers appeared both in the list. Also very general words like company were still included. This first selection of terms was elaborated by using them as search items in the database Web of Science and chosen or excluded based on the papers found. Web of Science was selected due to its interdisciplinary nature. In this way, the horizon of papers and topics relevant for the service purchasing literature was kept broad.

\footnotetext{
1 Rapidminer is a data science platform which offers-among others-functions for data mining.

2 In Rapidminer to process a text each phrase is broken up in its elements (words, symbols), which are called Tokens. This is operationalized in the program with the "Tokenize"-operator. For further information see Verma et al. (2014).
} 
Table 2 Keywords used for the systematic literature review
Three groups of keywords

(service* procure*) OR (service* buy*) OR (service* sourc*) OR (service* purchas*)

(buy* sell*) AND (servic*)

(consumer serv* quality) OR (serv* marketing value)

Table 3 Overview of the databases and settings used

\begin{tabular}{lll}
\hline Database & Search in & Language \\
\hline ABI/INFORM COLLECTION (ProQuest) & Title & English \\
ECONLIT (EBSCO) & All (Title, Abstract, Text) & English \\
SCIENCEDIRECT (Elsevier) & Title & English \\
WEB OF SCIENCE (Thomson Reuters) & Title & English \\
\hline
\end{tabular}

Combined with a backward search of the papers already read, additional keywords were retrieved from the literature on service quality based on Parasuraman et al. (1985) and their SERVQUAL-model. A backward search refers to "reviewing the references of the articles" already found (Webster and Watson 2002, p. 16). Van der Valk (2008), for example, makes frequent links to Grönroos (1984), who provides insights on the nature of services in the marketing context. This resulted in three groups of keywords listed in Table 2, which were linked with Boolean operators (i.e. AND, OR). If there were variations for certain keywords the asterisk [*] was inserted to attain all variants, i.e. to stem the keywords (e.g. for the keywords buying, buyer, buyers and buying the term buy* was used).

\subsection{Identification of databases}

The goal of the next process step was to identify the databases, which retrieve the relevant publications on BuSe purchasing by means of using the keywords. The service purchasing literature is a sub-category of the business administration literature. Additionally, databases from literature reviews in similar fields were included, for example, from the previous review by Nordin and Agndal (2008) or the review by Müller and Stölzle (2016) on the topic of supply chain management. The four databases ultimately chosen were ProQuest, EBSCO, ScienceDirect and Web of Science.

Next, the settings in each of the databases were tested and defined. First, depending on the options of the specific database, the search was limited to peer-reviewed journals and publications in English. This resulted in a very high number of hits. For example, more than 69,000 results were returned for the keyword group (buy* sell*) AND (servic*) in ProQuest. This lead to the decision to limit the keyword search to the titles of the publication in three of four databases (see Table 3 ). 
Table 4 Overview of the generated hits in the respective databases

\begin{tabular}{lcc}
\hline Databases & Hits & Relevant $^{\mathrm{a}}$ \\
\hline ABI/INFORM COLLECTION (ProQuest) & 345 & 36 \\
ECONLIT (EBSCO) & 312 & 7 \\
SCIENCEDIRECT (Elsevier) & 189 & 51 \\
WEB OF SCIENCE (Thomson Reuters) & 383 & 24 \\
Total & 1229 & 118 \\
\hline
\end{tabular}

${ }^{\mathrm{a}}$ No duplicates, focus on $\mathrm{B} 2 \mathrm{~B}$ and ranked journals in $\mathrm{VHB}$ and/or CABS

\subsection{Data extraction}

Our search settings resulted in 1229 hits, which had to be reduced to a more manageable number of papers. As the same keywords were used in different databases, the result contained 420 duplicates. These duplicates were eliminated which ended in 809 unique papers, which were further considered. After having read the abstract of these 809 articles, those related to B2C or papers wrongly classified by the databases (for example, wrong subject area, language, subject matter) were excluded from further examination.

In order to further narrow down the extensive literature and to ensure the quality of the articles reviewed, we followed an approach suggested by vom Brocke et al. (2015). As a rough proxy for quality, we only considered papers from journals that were listed either by the German Academic Association for Business Research $(\mathrm{VHB})^{3}$ or the Chartered Association of Business Schools (CABS). ${ }^{4}$ This reduced the number of papers to 118, which were then part of further analysis (Table 4).

\section{Bibliometric analysis}

After having identified the 118 publications, they were bibliometrically analyzed. Bibliometric in this context refers to a "method [that] employs a quantitative approach for the description [...] of published research" (Zupic and Čater 2015, p. 430). The idea is to reveal and describe the general structure of the body of literature without going into detail about the topic at hand. Therefore, the body of literature is aggregated and analyzed with data mining tools (aggregation, author, co-authorship and co-citation analysis) to gain "insights into the field's structure [and] social networks" (Zupic and Čater 2015, p. 430). The more advanced analyses (co-citation analysis) used a software called VOSviewer. ${ }^{5}$ It enables researchers to grasp the most relevant journals, institutions and networks in the BuSe purchasing literature

\footnotetext{
${ }^{3}$ Full list from 2011: http://vhbonline.org/vhb4you/jourqual/vhb-jourqual-archiv/vhb-jourqual-21-2011/ jq21\%.

4 Full list from 2015: https://charteredabs.org/academic-journal-guide-2015-view/.

5 VOSviewer is a free visualization-tool for bibliometric networks (www.vosviewer.com). For an exact explanation of the inner workings of the program consult Van Eck and Waltman (2010).
} 


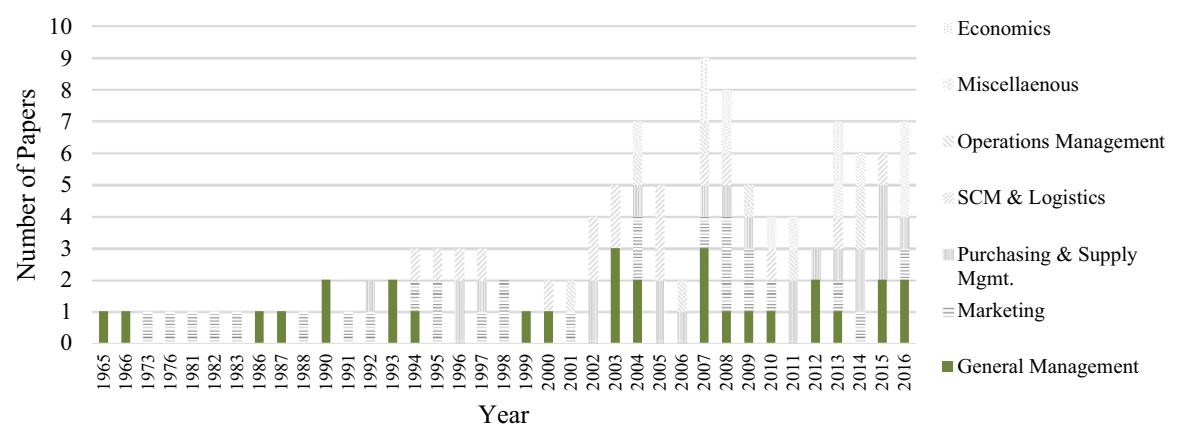

Fig. 2 Articles per journal groups over time

Table 5 Authors per geographic region and average year of associated publications

\begin{tabular}{llll}
\hline & North America & Europe & Asia and Oceania \\
\hline $\begin{array}{l}\text { Percentage and number of authors per geo- } \\
\text { graphic regions }\end{array}$ & $36 \%(95)$ & $57 \%(149)$ & $7 \%(18)$ \\
$\begin{array}{l}\text { Percentage and number of authors per geo- } \\
\text { graphic region since 2008 }\end{array}$ & $15 \%(19)$ & $70 \%(87)$ & $15 \%(18)$ \\
\begin{tabular}{l} 
Average year of associated publications \\
\hline
\end{tabular} & 1998 & 2008 & 2012 \\
\hline
\end{tabular}

(Fahimnia et al. 2015). This software requires that papers are available in a certain digital format. This condition was only fulfilled by 85 of the 118 papers retrieved. Thus, those analyses were based on a limited corpus. The simpler analyses included the full list of 118 publications, which were manually analyzed regarding the listed authors, the associated institutions and the journal of publication and citations.

The results seen in Fig. 2 show that the literature on purchasing of BuSe has developed from a minor topic in the marketing and general marketing literature to an emancipated research subfield from 1965 to 2016. Most articles in this area were published in the Journal of Purchasing and Supply Management whereas Industrial Marketing Management was the journal of choice for older publications. Since 2010, purchasing of BuSe became a more prevalent issue in journals related to economic or political affairs (see, for example, Bardsley and Burfurd 2013; Jamalzadeh et al. 2008). This potential surge in interest is also reflected in the sheer number of papers as $73 \%$ ( 86 papers) of the corpus were published from 2000 onwards. The growth in the number of publications can be partially explained by the general rise of the number of scientific articles published. This is estimated to amount to $3 \%$ per year (Jinha 2010, p. 262). The growth rate of the number of papers in our corpus of literature, however, exceeds this trend by a wide maring of $19 \%$. It therefore seems that there is a heightened interest in the subject matter. Geographically, a shift in terms of number of publications from American to European universities can be observed (Table 5).

In particular, North European universities such as Stockholm School of Economics, Erasmus University or Lappeenranta University of Technology hold a significant 
share of publications. The associated researchers have predominantly a background in supply chain management and purchasing, although marketing-oriented researchers are present as well.

Until the 1990s exactly half of the publications in the corpus were published in the area of marketing. This started to change during the turn of the millennium with a "general increase in interest towards purchasing organizations" (Schneider and Wallenburg 2013, p. 145). During this period, an emancipation of purchasing as a separate function with its own publications, for example, the European Journal of Purchasing and Supply Management could be observed (cf. Bryntse 1996). This was also accompanied by an increasing interest for purchasing in research areas such as logistics, SCM or operations management (see Fig. 2). In the 2000s, publications emerged in a higher quantity, while being spread over a myriad of research branches. During this time publications under the classification "economics" and "miscellaneous" appeared as well. An example for the latter is the publication of Jamalzadeh et al. (2008), which looks at the "procurement of ancillary services" in the context of energy policy.

All in all, the bibliometric analysis suggests that the business service purchasing literature emerged from and is still dependent on the marketing literature.

In order to find the literature which is central to the academic discussion on BuSe purchasing, a co-citation analysis was conducted. The analysis calculates the "frequency with which two units are cited together". The assumption is that the "more two items are cited together, the more likely it is that their content is related" (Zupic and Čater 2015, p. 431). This allowed us to model a "co-citation network", which helps in assessing a "field's cumulative tradition and reference disciplines" concerning authors and individual papers (Pasadeos et al. 1998, p. 55). The threshold for individual articles to be listed in the co-citation analysis was that they are at least nine times co-cited with another publication in one of the papers. Nine co-citations maximized the number of co-citations, while maintain a big enough number of articles. ${ }^{6}$ This reduced the total of 3227 references found in the limited ${ }^{7}$ corpus to 15 articles, which throughout are the most commonly co-cited (listed in "Appendix"). Figure 3 visualizes the 15 articles and places them in a spatial relation, i.e. the closer two articles are the more often they were cited together. The analysis of the most cocited publications supports the previous findings about the importance of the marketing literature but paints a more nuanced picture. While marketing scholars such as Parasuraman et al. (1985) und Håkansson (1982) are prominently positioned, the most important publications identified in the co-citations analysis for the topic of BuSe stem from the area of service purchasing itself. Especially, the publications by Axelsson and Wynstra (2002) and Wynstra et al. (2006) play a crucial role as they were cited 30 times throughout the limited corpus and thus laid important foundations for almost all subsequent articles, specifically, regarding service classification.

\footnotetext{
68 co-citations resulted in 18 articles, while 10 co-citation reduced the number of articles to 8 .

7 Only 85 articles out the 118 were available on Web of Science digitally and could therefore be included in the co-citation analysis in VosViewer.
} 


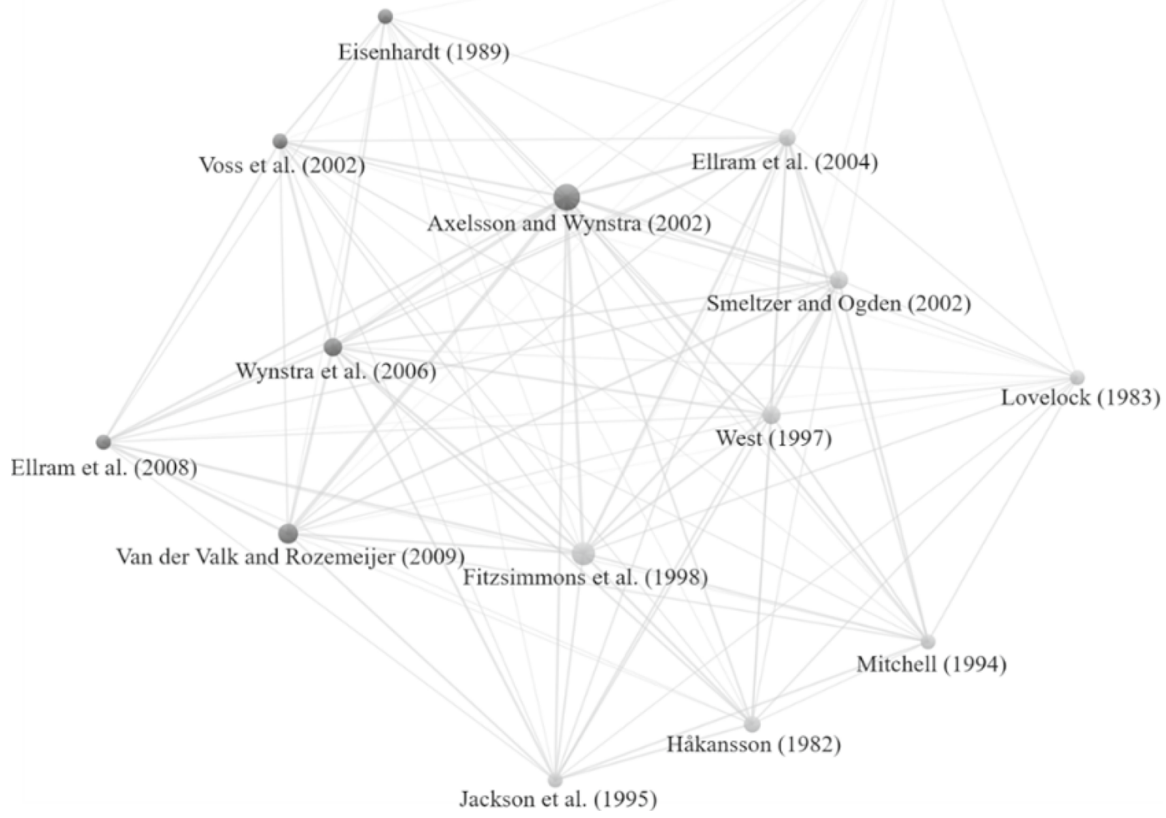

Fig. 3 Visualization of the 15 most co-cited publications in the limited corpus

The co-citation analysis also reveals a theoretical debate about the rationale of the purchasing function in general. Many authors try to understand the parties involved in the purchasing process on account of different interests using the agency theory (Eisenhardt 1989), whereas others regard purchasing as a function for cost optimization in terms of transactions based on Williamson (1975). As Voss et al. (2002) show, this debate is far from being concluded. This analysis also reveals the challenge between establishing general frameworks or models and acknowledging the interactive, relational nature of service exchanges as described, for example, by Grönroos (2000) and Håkansson (1982).

\section{Content analysis}

The 118 papers were then further analyzed in terms of four dimensions which broadly cover the research field of business service purchasing. These four dimensions were: (a) theoretical underpinning, (b) methodological basis, (c) industry and service purchased, and (d) purchasing process for services.

The four dimensions were derived following a bottom-up coding approach, by which categories were formed while classifying. This approach was necessary because there were no "classification schemes available [...] for purchasing and supply management research" (Wynstra 2010, p. 280). This iterative process allowed for an 


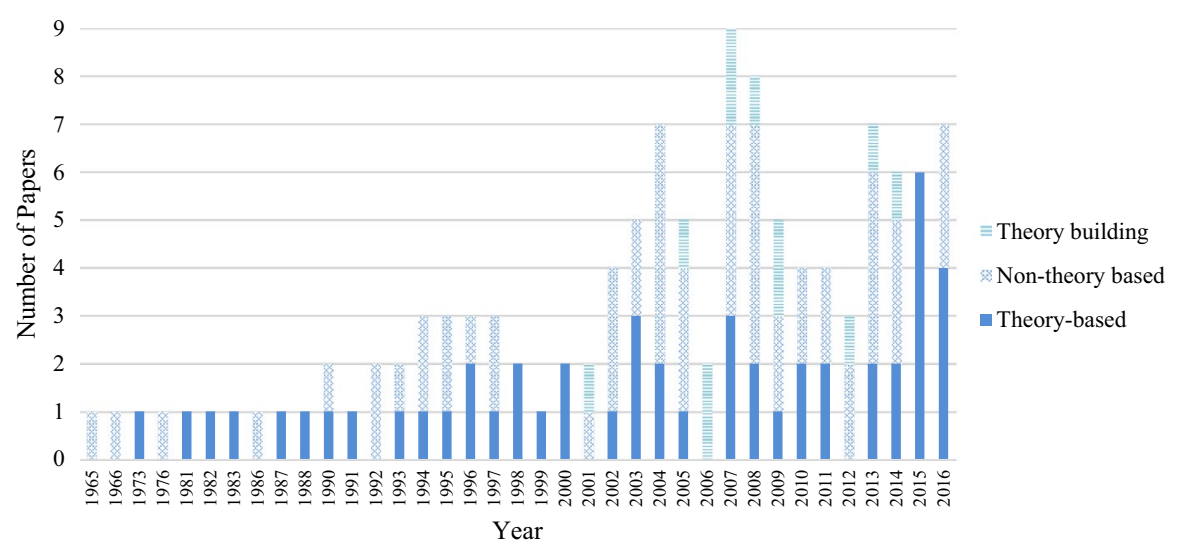

Fig. 4 Publications with a theoretical basis over time

"unbiased" consideration of literature, because the papers were not forced into ill-fitting pre-existing classes (Schneider and Wallenburg 2013, p. 145). Existing literature reviews for adjacent research fields helped in formulating and building categories (for example, Müller and Stölzle 2016; Wynstra 2010; Nordin and Agndal 2008; Seuring 2003). The categories initially obtained were iteratively assessed and re-applied during the process in order to attain accurate results (Carter and Ellram 2003).

First, the dimension "theoretical underpinning" was examined by checking whether the publications were based on a theory. Each of the 118 publications was scanned for references to a theory, which resulted in 50 publications (42\%), depicted in Fig. 4.

The analysis unveiled a shift in the theoretical characteristics of the literature. While more than half $(57 \%)$ of the publications written before the year 2000 were based on a clearly stated theory, this was only true for $37 \%$ of articles published from the year 2000 onwards. Over the whole period, the theories mostly applied are transaction cost theory by Williamson and agency theory by Eisenhardt. A list of the mentioned theories can be found in the "Appendix". From 2000 onward, a substantial number of theory-related articles deal with theory building and apply an approach based in grounded theory (cf. Benjamin et al. 2014; Cox et al. 2007; Gligor and Holcomb 2013; Schiele 2005; van der Valk 2008; Wynstra et al. 2006). Additionally, this literature does not focus on testing theories but instead on typologies of service interactions (cf. van der Valk and Wynstra 2014) or service characteristics (cf. Werr and Pemer 2007) to construct frameworks. This is in line with the observations by Nordin and Agndal (2008) in the empirical service sourcing literature. They note that publications in the BuSe purchasing field are "typically inclined towards descriptions of practices without any explicit linkages to theoretical perspectives at a higher level of abstraction" (Nordin and Agndal 2008, p. 33).

This development could also be a sign of an increasing emancipation of the topic of purchasing in general and of BuSe purchasing in particular. The foundation of specialized journals such as the Journal of Purchasing and Supply Management went together with more articles dedicated to empirically-driven theory building. This is consistent with the "evaluation of a discipline"-framework from Harland 


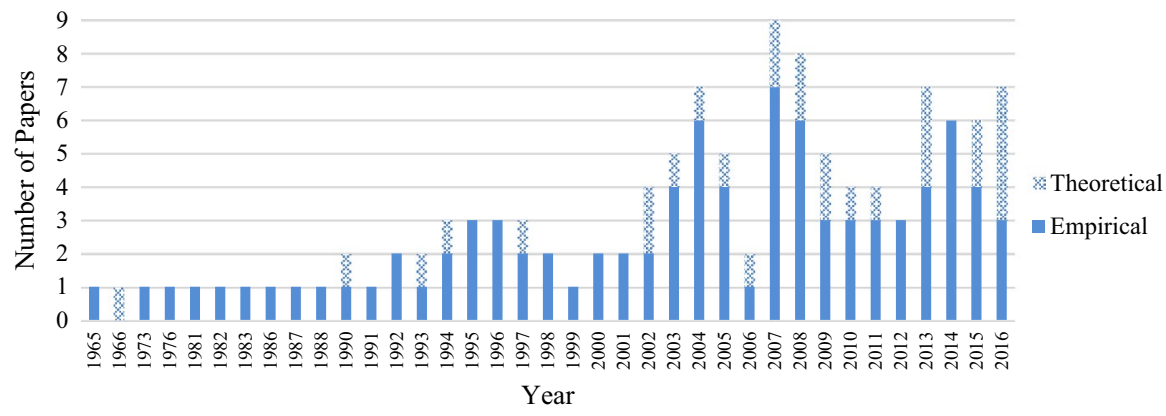

Fig. 5 Number of paper either empirical or theoretical over time

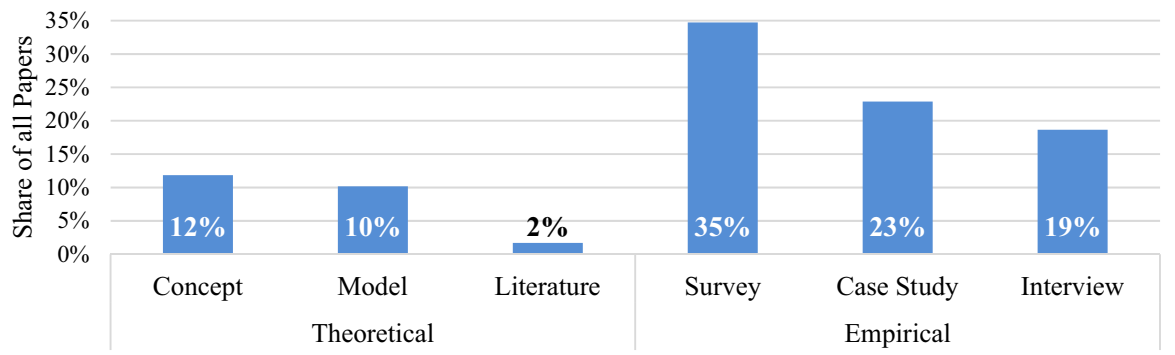

Fig. 6 Methodological foundation of all papers written

et al. (2006, p. 734), exemplifying the transition from a debate about content to the establishment of an emergent new discipline.

Second, the methodological basis of the corpus was analyzed. First, the publications were very broadly categorized as either being empirical (i.e. dependent on empirical findings) or theoretical (i.e. dependent on pre-existing models, theories or concepts). This revealed that 90 (76\%) articles of the corpus can be classified as using an empirical foundation (see Fig. 5).

In the empirical publications' surveys, case studies, interviews or combinations of these were mostly employed. Examples for a combination are Hawkins et al. (2015) or Pemer et al. (2014), who used an initial set of interviews to conduct a survey afterwards.

Publications with a theoretical foundation were also classified in three categories. These papers either drew heavily form pre-existing concepts, quantitative models or reviewed literature. The results from this analysis are presented in Fig. 6.

41 articles (35\%) were based on survey-data while those publications mostly base their research on primary survey data. Only rarely secondary survey data were used for an article (see, for example, Dobrzykowski et al. 2012). Another pattern, which manifested in all empirically based publications, was their crosssectional perspective. The information these papers use relate to one specific point in time and is then generalized. An exception was the paper by Ojansivu et al. (2013), in which case study data that spanned more than a decade, was used to reveal the "underlying dynamics of the post-project stage that plays out over 
Table 6 Matrix of papers written in the categories of service industry and service type

\begin{tabular}{|c|c|c|c|c|c|c|c|}
\hline & \multicolumn{7}{|c|}{ Industry of the buying company } \\
\hline & Other & Public sector & Manufacturing & Logistics & Mix & General & Total \\
\hline \multicolumn{8}{|l|}{ Type of BuSe } \\
\hline Other & 2 & 7 & 1 & & 8 & 7 & 27 \\
\hline Food-related & 3 & & & & & & 3 \\
\hline Financial & & & & & 3 & 1 & 4 \\
\hline Health-related & 1 & 2 & & & 1 & & 4 \\
\hline Consulting & 2 & & & & 2 & & 4 \\
\hline IS/IT & 1 & & 1 & 1 & 2 & & 5 \\
\hline Facility & 2 & 3 & & 1 & & & 6 \\
\hline Logistics & 5 & 1 & 2 & & 11 & 1 & 20 \\
\hline Mix & & 2 & 2 & 12 & 5 & & 21 \\
\hline General & 5 & & 3 & 1 & 9 & 8 & 26 \\
\hline Total & 21 & 15 & 9 & 15 & 41 & 17 & 118 \\
\hline
\end{tabular}

time". Furthermore, the comparably low amount of publications that reviewed literature is remarkable. The only publications found that mainly focus on a literature review in a specific topic are Holmlund et al. (2016), Fulconis et al. (2016) and the initially found paper by Nordin and Agndal (2008).

The body of literature in the BuSe purchasing is mostly based on an empirical basis, which matches with the assessment of research being focused on practical implications in the previous section. Surveys are the most widely used tools of researchers in this field to collect their data, while comprehensive literature reviews are practically non-existent.

Third, it was analyzed in which industry the buying firm is active and what type of service is in focus. Considering this perspective was mostly motivated by the writings of Smeltzer and Ogden (2002, p. 69), who proposed that "purchasing services varies across organizations". Geisler and Hoang (1992) found out that there are both differences in the definition of "need" across companies when buying IT services as well as in the subsequent buying process. Wynstra et al. (2006) stress that varying buyer-seller interactions are "related to different types of services" (p. 476).

Table 6 shows results of the analysis during which each paper was classified in a matrix for both service type and service industry. Nine types of externally sourced BuSe could be identified with each of them being mentioned in at least three publications. A substantial amount of papers focused on BuSe which did not form a service category of its own and were therefore assigned to the category "Other". The category "General" represents cases where the BuSe was not specified or examined from a general perspective. The category "Mix" is related to publications which dealt with several BuSe simultaneously.

The type of BuSe explicitly stated most frequently was "logistics services" with 21 papers $(18 \%)$. These publications investigate aspects of services provided by a logistics provider to a buying company (see, for example, Caplice and Sheffi 2003; 
Fulconis et al. 2016; Holter et al. 2008; Jothi Basu et al. 2015; Martin et al. 1988; Sheffi 2004; Zhang et al. 2013) and mainly focus on the relationship between the buyer and the seller (for example, Fulconis et al. (2016); Gligor and Holcomb (2013); Jothi Basu et al. (2015); Zhang et al. (2013). Spina et al. (2013, p. 20) state that this may be part of a general trend in the purchasing literature as there seems to be a shift of the "unit of analysis [...] from the buyer perspective to the supply network one", which is supposedly related to the trend of "outsourcing and globalization". "Facility" services receive moderate attention and are often researched from a public sector perspective (Ancarani and Capaldo 2005; Benjamin et al. 2014; Guercini and Ranfagni 2015). Both the category "General" and "Mix" contain more than a third of articles (39\%) and the topics often revolve around the improvement of quality, processes or definitions of service buying (Hawkins et al. 2015; Holschbach and Hofmann 2011; van der Valk and Rozemeijer 2009; Wynstra et al. 2006). The five remaining categories encompass too little publications for generalizations to be made. The full categorization again can be found in the "Appendix".

Furthermore, the analysis shows that authors in the area of purchasing of BuSe seem to aim at generalizing their findings without accounting for the industry the firm belongs to. Therefore, in 41 of the 118 cases they chose buying companies from a mix of sectors. This is somewhat surprising as the purchasing of services varies greatly amongst different industries (Smeltzer and Ogden 2002, p. 69). By contrast, the public sector is often specifically addressed (13\% of publications) because its purchasing processes and rationale differ from the private industry (Hansson and Holmgren 2011; Hawkins et al. 2015).

In addition, there seems to be a tendency towards generalizing findings to all types of services. Again, publications with mixed service types or an unspecified service item represent $40 \%$ (47 papers) of the corpus. Interestingly, logistics is frequently addressed both as service and industry and further explored in more recent literature whereas those publications mainly focus on the relationships management between the buyer and the seller (see, for example, Fulconis et al. (2016); Gligor and Holcomb (2013); Jothi Basu et al. (2015); Zhang et al. (2013). This seems to follow a trend in the purchasing literature as Spina et al. (2013, p. 20) discovered a shift of the "unit of analysis [...] from the buyer perspective to the supply network one".

Fourth, the literature was examined regarding the underlying purchasing process for BuSe. As van der Valk and Rozemeijer (2009) pointed out the purchasing process for BuSe is different than that for goods and should thus be defined in publications about the topic. The presumed differences between goods and services have prompted many authors to propose a specific purchasing process for services. Based on a comprehensive list of such processes by Holschbach (2013) a generic process model for purchasing of BuSe was created. Then, the 118 remaining publications were analyzed and wherever possible assigned to one of the process phases based on their thematic focus. The process model consisted of five different process phases (preparation, search, contracting, monitoring, and collaboration) as well as a category representing the whole or vaguely described purchasing processes. Furthermore, a category for the service buying department was introduced which mainly contains publications dealing with the rationale and the general function of the service buyer and/or the purchasing organization. 


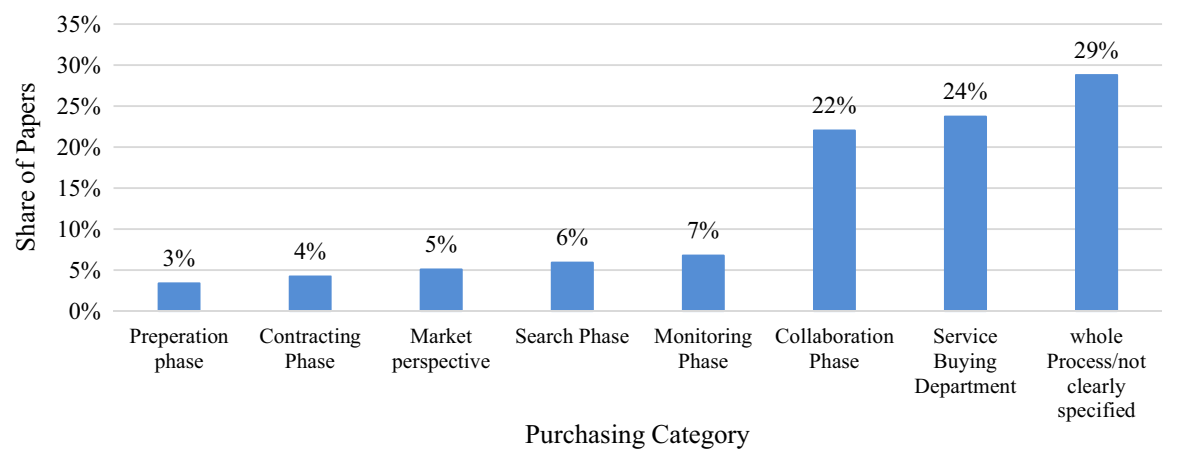

Fig. 7 Percentage of papers written, in which service purchasing process perspective

As Fig. 7 shows, most publications (29\%) dealt with the purchasing process for BuSe as a whole or did not clearly specify which phase of the purchasing process was under investigation. Some of the general processes are tailored to just one service type (for example, Holter et al. 2008). Other articles focus on a very basic buying process because services definitions are considered to be subject to dynamic change (for example, Gelderman et al. 2015), while others claim to have established a more general process model (for example, van der Valk and Rozemeijer 2009).

Publications, which could be assigned to the service department category (24\%) mainly deal with the rationale and the general function of the service buyer and/or the purchasing organization. A special focus seems to be on the network of the buyer based on personal relationships (for example, Lian and Laing 2007) and word-ofmouth effects (e.g. Money 2000). Another recurring topic is the question of a meaningful involvement of the purchasing department in the purchasing process introduced by Stuart (1991) and by Schiele and McCue (2006).

Furthermore, quite a significant share of publications (22\%) are concerned with the collaboration phase in the purchasing process. This may not be surprising considering the ongoing debate which questions differences between goods and services. Propagating a service-dominant logic, Vargo and Lusch (2004) consider all exchanges of goods and services as similar dynamic and continuous resource transactions between buyer and seller-thus relying heavily on the collaboration of these two parties. The service purchasing literature partially adopted this viewpoint and found a middle ground determined by the publications by Lindberg and Nordin (2008) and van der Valk and Rozemeijer (2009). Both stress the dynamics of interaction but do not refute all differences between goods and services. Thus, they claim a middle position between the goods- and service-dominant logic.

Only $25 \%$ of the publications deal with the remaining five phases of the purchasing process for BuSe. Articles dealing with the monitoring phase predominantly focus on the assessment of service quality from the perspective of the buying company (see, for example, Hawkins et al. 2015; Holschbach and Hofmann 2011; Large and König 2009; Stanley and Wisner 2002, additionally cf. Holschbach 2013) whereas papers examining the preparation phase mostly focus on make-or-buy decisions (cf. Espino-Rodríguez et al. 2008; Newton 1965; van Mossel and van der Valk 2008; 
Zimmermann et al. 2016). Furthermore, it is noteworthy that nearly all publications take a business-to-business perspective, i.e. they investigate how companies purchase BuSe from external service providers. Only three articles in the corpus examine how internal customers buy services from other organizational units within the same company (cf. Cox et al. 2005; Fredendall et al. 2005; Large and König 2009).

\section{Directions for the future}

Over the course of the bibliometric and content analysis the most important authors and topics were identified and presented. Although required, these retrospective analytical activities are not sufficient to build an agenda for future research. Therefore, the analytical results were further discussed within the research group of the authors complemented with insights of recent (consultancy) studies. This discussion resulted in the identification of six content-related research trends, which are expected to have a major influence on business service purchasing and are important for both researchers and practitioners alike. The trends are structured along the dimensions of the PEST-analysis, which is often used to analyse an "industry sector within a particular business environment" (Peng and Nunes 2007). Due to a political, economic, social and technological level, the PEST framework can help to assess position, potential and direction for a business sector (Gupta 2013):

- Political-level trends are determined by the general changes in the political climate, which influence how firms have to behave. Firms might have to adapt and adjust their strategies to these trends in order to cope with competition in the future.

- Economic-level trends influence and shape how firms purchase services, interact and generally conduct business with each other. This level is especially concerned with the "economic effects on suppliers" (Gupta 2013, p. 35).

- The social-level trend is concerned with the changes of "tastes and habits" of customers which influence the service items offered and the composition of the products (Gupta 2013, p. 39).

- The trends on the technological level are highly influential on "products, processes, and distribution channels" of businesses through their broad impact on the way business is conducted (Gupta 2013, p. 35). Recently, these trends are largely dominated by the industry 4.0 approach (Hofmann and Rüsch 2017; Nicoletti 2018).

The identified trends along the PEST-dimensions are depicted in Table 7. We now reflect these trends against the background of BuSe purchasing, noting that the list is not exhaustive and there might be further relevant developments to be considered in future research.

\subsection{Glocalisation and near-shoring}

The first trend goes back to a discussion which was initiated in the 1980s by Levitt (1983). He argued that firms should globalize, i.e. favor a global over a local strategy, 
Table 7 Six trends to consider in business service purchasing along the PEST-levels

\begin{tabular}{|c|c|c|}
\hline Level & Trend & Study (source) \\
\hline \multirow[t]{2}{*}{ (P)olitical } & "Glocalisation" and near-shoring & Miebach Consulting (2017) \\
\hline & $\begin{array}{l}\text { Sustainability and corporate social } \\
\text { responsibility (CSR) }\end{array}$ & $\begin{array}{l}\text { Darnall et al. (2017), Hoejmose and Adrien- } \\
\text { Kirby (2012) }\end{array}$ \\
\hline \multirow[t]{2}{*}{ (E)conomic } & Internal and external collaboration & $\begin{array}{l}\text { Hofmann et al. (2016), Oxford Economics } \\
\text { (2015) }\end{array}$ \\
\hline & $\begin{array}{l}\text { Value-driven contract and payment } \\
\text { systems }\end{array}$ & $\begin{array}{l}\text { Hofmann et al. (2016), Selviaridis and Nor- } \\
\text { rman (2014) }\end{array}$ \\
\hline (S)ocial & Hybrid products and servitization & Bustinza et al. (2013), Marciniak (2014) \\
\hline (T)echnological & $\begin{array}{l}\text { Big data analytics, artificial intel- } \\
\text { ligence and process automation }\end{array}$ & Oxford Economics (2015), Stank et al. (2011) \\
\hline
\end{tabular}

to exploit benefits of standardization. Critical academics like Boddewyn et al. (1986) reacted by stressing the importance of local strategies. Firms seemed to mostly follow a globalization approach, which meant reducing vertical integration through outsourcing or relocating production in low-cost countries. This strategic choice became prevalent during the 1990s and 2000s (Miebach Consulting 2017). Globalization was observed with rising skepticism by many national states and societies which led to what many call a new wave of protectionism from the mid-2000s to today (Mordecai 2005; Williams and Denning 2009). The current trend towards protectionism combined with advanced production techniques and a demand for faster delivery times may result into higher levels of "glocalisation" and near- and even on-shoring. "Glocalisation" is a portmanteau of global and local and "represents the interlocking duality of globalization versus localization in cultural change and formation" (Wu 2008, p. 69). This trends manifests in globally active firms relocation their production near to or even back into their-local—sales market with the help of technology.

With regard to purchasing of BuSe the development may open up an array of options in terms of finding the right balance of "glocalization". More specific, it is about surpassing a simple labor cost perspective and finding the right value-contributing factors. Specifically, Kotabe and Murray (2004) suggested different sourcing strategies for core and non-core service activities. This aspect should be further explored from a "glocal" perspective. The decision whether an externally sourced service is core or non-core is a critical one which must be made individually. It is also essential which factors are included in a decision on off-, near-, or on-shoring. Additionally, culture is an often-overlooked aspect when investigating purchasing of BuSe. In most cases, it is assumed to be universal (Gligor and Holcomb 2013; Pemer et al. 2014). Considering today's potential surge in protectionism it should receive more attention by practitioners and academics alike.

\subsection{Sustainability and corporate social responsibility (CSR)}

A second trend is closely related to developments such as "population growth, shifting consumption patterns, uncertain growth projections, and increased disruption risks" 
(Quarshie et al. 2016, p. 93). These result in a so called "VUCA"-world as described by van Tulder (2017). ${ }^{8}$ Companies in such an environment have to adapt their longterm strategy to societal, environmental and market demands. This may grant them legitimacy which is often described as a license to operate (van Tulder 2017). The urge to obtain a license to operate made many companies seek sustainability and corporate social responsibility (CSR). In the literature the roots of this trend can be traced back to the Brundtland Report of the Brundtland Commission (1987) and the triple bottom line by Elkington (2002), ${ }^{9}$ while again being invigorated by the UN through the sustainable development goals for 2030 (United Nations 2015).

In the business purchasing literature the topic has received limited attention so far except by publications focusing on the reduction of carbon emissions in the logistics service literature (Jothi Basu et al. 2015). When looking at the literature on buying BuSe, this development seems to be neglected so far which was already noted by Holmlund et al. (2016). On a larger scale, the connection to the concept of a circular economy as described by Murray et al. (2017) could bring an additional perspective in the business service purchasing literature and may help firms position themselves adequately. Finally, we suggest to further explore how service purchasing can contribute to sustainability issues not only by focusing on environmental aspects but also by stressing social issues (e.g. compliance of the service supplier with working safety regulations or other labor standards).

\subsection{Internal and external collaboration}

The next trend stems from the competitive landscape in business-to-business markets which demands efficiency, flexibility and outstanding service offerings. Firms reacted to this challenge by offering comprehensive value chains or recently even complete eco-systems to their customers instead of single products or services (Schröter et al. 2005). In this way, collaboration with other companies became more important. This development already started in the 2000s as noted by Horvath (2001, p. 207), who proclaimed that competitive advantage does not mean anymore to "erect technical barriers to rivals" but to transform business processes in a network. The imperative of efficiency on the network-layer naturally trickled down to the individual firm, which had to improve its internal collaboration. In some aspects, this proved to be more difficult than the external collaboration with suppliers (Sabath and Whipple 2004, p. 1). Consequently, internal collaboration was declared one of the five pillars of supply chain excellence by Stank et al. (2011). This general trend has intensified in recent years because the pressure for efficiency has increased due to an more and more technology-driven business environment (Oxford Economics 2015).

In the business purchasing literature the collaboration between buyer and supplier does not seem to be adequately addressed yet (van der Valk and Wynstra 2014). This is mainly due to the challenges and dynamics of defining the service attributes by buyer and service provider during the collaboration phase. Therefore, research

\footnotetext{
8 VUCA stand for Volatile, Uncertain, Complex and Ambiguous (van Tulder 2017, p. V).

${ }^{9}$ The triple bottom line aims to measure the financial, social, and environmental performance of a company over time.
} 
by Gelderman et al. (2015) on the dynamics of service definition of ICT (information and communication technology) services should be expanded. This entails the exploration of differences between services or interaction modes. Cox et al. (2005) and Fredendall et al. (2005) established the topic of internal collaboration as a research area to consider, while Large and König (2009) focused on the subtopic of monitoring internal service quality. Another question which so far did not receive much attention is how digitalization (for example, big data analytics, machine learning or blockchain technology) might change the narrative and dynamics of those internal and external service interactions.

\subsection{Value-driven contract and payment systems}

The following trend is closely tied to firms offering value to a buyer through an extended firm network. As Melnyk et al. (2010, p. 33) noted a new paradigm is forming, in which the formerly "strategically decoupled and price driven" supply chains are becoming closely strategically integrated and "value driven". The collaborative nature demanded by such business relationships results in high transaction cost, high risk and moral hazards among the parties involved (Randall et al. 2010). These changes have to be considered in contractual agreements and different interests have to be aligned in order to provide the best possible service offering. This strategy is known as performance-based contracting (PBC), performance contracting, performance based logistics (in the military context) or by "power by the hour" in the airline industry (Selviaridis and Wynstra 2015). PBC ties contractual payments to the desired performance and thus shifts most of the risk to the service provider (Kim et al. 2007).

In the business services purchasing literature analyzed in this corpus the topic of performance-based contracts did not receive much attention, yet. More recent publications (not included in the corpus) by authors such as van der Valk, Sumo and van Weele have started to address this gap in the literature. The main focus of those is how PBC can foster innovation in business relationships concerned with IT outsourcing (for example, Sumo et al. 2016a, b). Future research should expand their findings in light of the specific service aspects and thus widen the comparably narrow perspective. Furthermore, Sumo et al. (2016a) strongly suggested diving into the "collaboration's history" and its effects on the contractual agreement. Another interesting effect of PBC is the shift of risk to the supplier which should be explored in more depth regarding its relationship to service items and firms involved. One last promising research area is how the performance can be adequately defined during the service purchasing process. Related to this, Gelderman et al. (2015, p. 225) pointed out that frequent and dynamic changes of service definitions during the purchasing process may challenge "over-optimistic confidence" in PBC.

\subsection{Hybrid products and servitization}

Vandermerwe and Rada (1988, p. 314) first introduced the notion of "servitization". They predicted that the service would influence classical manufacturing firms, 
which would extend their product portfolio with combinations of tangible products and services. They identified the trend to be mainly "customer demand-driven" and prevailing in all industries (Vandermerwe and Rada 1988, p. 314). As Lightfoot et al. (2013, p. 1413) explains products subsumed under this trend "tend to be delivered using customer centric strategies in order to provide 'desired outcomes' for the customer". The two authors proclaimed: "services are no longer a separate category for managers to consider, but rather an all-pervasive part of their strategic mission and corporate planning". As Priya Datta and Roy (2011) explain, services have become a critical part of competitive advantage. Additionally, several studies have shown that servitization is a source of increased profits (Eggert et al. 2014) and customer retention (Gaiardelli et al. 2014). The trend manifests today in so called "hybrid products", where both product and service elements have been integrated in offerings.

Servitization has fostered new service-centered literature mostly by following the service-dominant logic by Vargo and Lusch (2004). By contrast, most publications in the literature on BuSe purchasing are focused on "conventional" services without specifically addressing hybrid products. Product-service hybrids offer interesting areas to explore, however. For example, the question how ownership can change while consuming construction services may be an interesting area of research (cf. Caldwell et al. (2009). Another valuable question to answer may be how the hybrid service approach positions itself between the product and service purchasing model.

\subsection{Big data analytics, artificial intelligence and process automation}

The technological change in the last years is one of the most prevalent and highly publicized topics. Companies like Amazon, Uber or Airbnb are epitomes of how digitalization and the use of big data, machine learning and artificial intelligence (AI)shaped and changed markets. Since the 1990s, the internet has spurred the development of new business models to an extent which Fleisch et al. (2015, p. 1) caused to proclaim that "the separation between physical and digital industries is now consigned to the past". This change was mainly driven by the growth in digital data produced by firms from the 2000s onwards as well as the astonishing developments in processing speed which allowed to analyze these data and optimize and adapt whole business models (Marz and Warren 2015; Russom 2011). Along with industry 4.0 developments (Hofmann and Rüsch 2017), it is expected that supply management will develop towards "procurement 4.0" (Nicoletti 2018). According the consultancy company "Strategy\&", procurement 4.0 encompasses the following areas: (1) New procurement value proposition, (2) digital category and service procurement, (3) digital supply chain and supplier management, (4) innovative procurement data utilization, (5) digital processes and tools, and (6) digital organization and capabilities, ${ }^{10}$ all of them also affecting business service purchasing.

In the service literature Ostrom et al. (2015) identified the usage of big data as one of the key research topics, while finding the widest gap between state of knowledge

$\overline{10}$ https://www.strategyand.pwc.com/report/procurement-4-digital-revolution. 
and expected importance in this area. This research also identified seven different research subtopics, from which three can be directly applied to the BuSe purchasing literature. First, the question of which information in service purchasing contexts needs to be collected should be further explored. Second, it would be interesting to investigate how collected data can be used by machine learning algorithms and AI in order select the best service bundle and the "right" provider during the purchasing process for BuSe. Third, it is still to be clarified how these data and methods can be used for service innovation in an established collaborative business relationship (Ostrom et al. (2015). Fourth, it is of interest to elaborate how machine learning and AI could be applied (1) to prevent service ordering and processing errors or (2) to deepen the ex-post as well as ex-ante performance of service providers. Service innovation can particularly be regarded a crucial topic as "large companies rarely put as much sustained effort and management attention into transforming services as they do with products" (D'Emidio et al. 2015, p. 1). The question to answer is, for example, how service innovation can be institutionalized and become a source of competitive advantage. Finally, it would be of interest to examine how the usage of blockchain technology (BCT) and smart contracts will be foster the digitalization of the (service) purchasing function.

\section{Concluding remarks}

The purchasing of services undoubtedly plays an important role for each company in a service economy. As Ellram and Tate (2015, p. 64) emphasize, services "contribute both as source of cost and as a source of performance improvement" to the success of today's firms. This "state of research" paper has presented a structured literature review of the business service purchasing literature. The paper analyzed 118 publications in the area of purchasing of BuSe to answer three main research questions.

\subsection{Research results}

RQ1: Current state of research on business service purchasing The analysis clearly unveiled a shift in the literature over the 51 years in scope. The literature on BuSe purchasing somewhat mimics the development of the general purchasing literature. More specifically, it follows the way from "buying, via procurement to supply management" as described by Axelsson and Wynstra (2002, p. 15). Research on purchasing of BuSe developed from a minor topic in management and marketing publications via the more mature contributions in purchasing journals to today's articles in which the topic is reflected from various perspectives such as policy making and economics. The most important network of authors and researchers in this area has formed in Northern Europe around the Stockholm School of Economics, the Erasmus University and the Eindhoven University of Technology with authors such as Axelsson, Sumo, van der Valk, van Weele, and Wynstra. 
RQ2: Theoretical and methodological gaps in the field of business service purchasing The second research question is related to research gaps. The biggest gap, which was uncovered through the content analysis was the comparably meagre theoretical foundation. Most recent literature omits a clear stated theory or pursues theory building. This gap should be further filled in order to clarify the rationale for the purchasing function and its operation. The second gap is methodological in nature and could, if properly researched, help to better understand business service purchasing. Most research is cross-sectional in nature, based on a snapshot (i.e. onetime interviews or surveys) and uses this data to generalize. Research should hence be conducted with a longitudinal perspective to confirm the empirical research and control for case specific variables. The third gap is about the differences between service types and/or sectors. Although Hänsel and Hofmann (2016, p. 9) declared that the difference between service types is a necessary variable to consider for the development of a service evaluation tool, most literature does not differentiate between different types of services. It is noteworthy that often a mixed approach is chosen which makes replication studies difficult. Other gaps that should be addressed are the differences between indirect and direct services, the internal purchasing process perspective. Finally, authors should focus more on separate purchasing process steps (e.g. preparation, search, contracting, monitoring, collaboration).

RQ3: Topics that need to be addressed in the future by business service purchasing? The third research question was aimed at uncovering the most important topics to pursue for the future of the business service purchasing literature. Specifically, six trends along the PEST-framework were highlighted as potential perspectives for future research. The common denominator is that business service procurement has become a strategic aspect of gaining competitive advantage in today's service economy. The strategic role means that questions of value contributions are of prime interest and should thus be researched. Business service purchasing is confronted with questions of value contribution-whether it is about finding the decision factors for the right "glocal" balance, about how to contribute to CSR goals or about the way service definitions change in a company network. The topic of applying big data analytics, machine learning and AI in the service purchasing field as well as the digitization of the (service) purchasing function itself holds comparably large potential for new insights due to the complete lack of literature. Questions to answer are tied to what, where and how data will be collected and analyzed in order to optimize and automatize the business service buying process (including the selection of the best service offering bundle and the evaluation of the service providers). Furthermore, it is of interest where and how new technical developments-like the usage of blockchain technology—will change behavior and activities in BuSe purchasing.

\subsection{Managerial implications}

We believe that it is of paramount importance for managers to recognize the strategic importance of service purchasing. The role of purchasing professionals will likely become a highly skilled and cross-functional one as the complexity of service 
bundles and service provider networks increases. Furthermore, questions of purchasing governance and of structured as well as automated service purchasing processes will become more prevalent. This process of professionalization of service purchasing should be realized together with the development of a digitization strategy, i.e. purchasing processes have to be created and implemented with digital means in mind. The objective is to make comparably fuzzy service exchanges as transparent as possible in order to guarantee high quality, recognize optimization potential and enable service innovation through predictive analytics, machine learning and AI. More strategically, the view on service purchasing has to shift from cost reduction to value contribution. For example, this could be taken into account in the contracting phase, where bids of suppliers should be assessed based on factors such as alignment with the sourcing strategy, their digital maturity degree and/or their sustainability compliance. Furthermore, service contracts should be designed using a performance-based logic. This could assure proper alignment of interests through a risk and reward design. Overall, the development should lead to a stronger collaboration with providers in which strategies like data sharing are used to improve and deepen service ecosystems. Management needs to find the balance between allowing each firm enough autonomy for innovation and the realization of performance goals.

\subsection{Limitations}

The paper is limited by several factors linked to the method of the review and practical aspects such as time. The premise of the whole work is that the 118 papers in the corpus are an accurate representation of the BuSe purchasing literature. Regarding this, three aspects need to be noted. First, the sample collection is strongly tied to the initial reading of selected publications and puts great trust in the reliability of the databases used. Second, the process of filtering the initial corpus of 1229 publications to 118 was based on reading and thus is error-prone in approach. Third, the restraint to English-speaking, scientific and CABS/VHB rated articles left out publications with a more practical perspective. Another limitation may be rooted in the analysis itself. First, it has to be stressed that the analysis was conducted in a bottom-up coding approach to allow for an accurate classification. This means that the classifications are tied to the judgement of the researchers and thus are prone to bias. Second, the co-citation analysis and the cited literature-analysis was based on a reduced corpus, which only consisted of $72 \%$ of the original papers, due to data availability issues. Third, the scope of the analysis was intentionally kept wide which limited the specificity in which topics could be discussed and again forced the researchers to highlight topics they deemed important. Future literature-based research should improve the use of data mining tools and better connect qualitative assessments with quantitative tools. Specifically, such tools could help to clarify terms and single out unfitting publications in the early stages of the research and the filtering process. At the same time they could help in managing a larger number of articles. Additionally, future research should focus more on specific aspects of the service purchasing literature mentioned in this paper. 


\section{Appendix}

\section{Appendix 1: Alphabetical list of the 118 papers in the corpus}

Agndal, H., Axelsson, B., Lindberg, N., \& Nordin, F. (2007). Trends in Service Sourcing Practices. Journal of Business Market Management, 1(3), 187-208.

Alexander, K. (1993). Sourcing the facilities service. Facilities, 11(5), 24.

Alexandersson, G.H., Staffan. (2007). High and Low Bids in Tenders: Strategic Pricing and Other Bidding Behaviour in Public Tenders of Passenger Railway Services. Annals of Public and Cooperative Economics, 78(2), 161-194.

Ancarani, A., \& Capaldo, G. (2005). Supporting decision-making process in facilities management services procurement: A methodological approach. Journal of Purchasing and Supply Management, 11(5-6), 232-241.

Andersson, D., \& Norrman, A. (2002). Procurement of logistics services-a minutes work or a multi-year project? European Journal of Purchasing \& Supply Management, 8(1), 3-14.

Anthon, S.B., Peter; Thorsen, Bo Jellesmark. (2007). A Bureaucrat's Procurement Strategy: Budget Constraints and Rationing. Annals of Public and Cooperative Economics, 78(2), 221-244.

Bardsley, P.B., Ingrid. (2013). Auctioning Contracts for Environmental Services. Australian Journal of Agricultural and Resource Economics, 57(2), 253-272.

Barragan, S., Cappellino, C., Dempsey, N., \& Rothenberg, S. (2003). A framework for sourcing product development services. Supply Chain Management: An International Journal, 8(3), 271-280.

Benjamin, O., Nisim, S., \& Segev, G. (2014). Corporate Social Responsibility as Shaped by Managers' Role Dissonance: Cleaning Services Procurement in Israel. Journal of Business Ethics, 130(1), 209-221.

Bienstock, C.C. (2002). Understanding buyer information acquisition for the purchase of logistics services. International Journal of Physical Distribution \& Logistics Management, 32(8), 636-648.

Bowman, D., \& Lele-Pingle, S. (1997). Buyer behavior in business-to-business services: The case of foreign exchange. International Journal of Research in Marketing, 14(5), 499-508.

Bryntse, K. (1996). The purchasing of public services exploring the purchasing function in a service context. European Journal of Purchasing \& Supply Management, 2(4), 193-201.

Caloghirou, Y., Protogerou, A., \& Panagiotopoulos, P. (2016). Public procurement for innovation: A novel eGovernment services scheme in Greek local authorities. Technological Forecasting and Social Change, 103, 1-10.

Caplice, C.S., Yossi. (2003). Optimization-Based Procurement for Transport Services. Journal of Business Logistics, 24(2), 109-128.

Cooper, M.B., Dröge, C., \& Daugherty, P.J. (1991). How buyers and operations personnel evaluate service. Industrial Marketing Management, 20(1), 81-85. 
Cox, A., Chicksand, D., Ireland, P., \& Davies, T. (2005). Sourcing Indirect Spend: A Survey of Current Internal and External Strategies for Non-Revenue-Generating Goods and Services. Journal of Supply Chain Management, 41(2), 39-51.

Cox, A., Croom, S., Chicksand, D., \& Yang, T. (2007). The proactive alignment of sourcing with marketing and branding strategies: a food service case. Supply Chain Management: An International Journal, 12(5), 321-333.

Daugherty, P.J.S., Theodore P.; Rogers, Dale S. (1996). Third-party logistics service providers: Purchasers' perceptions. International Journal of Purchasing and Materials Management, 32(2), 23.

Day, E.B., Hiram C., Jr. (1994). Organizational purchasing of professional services: The process of selecting providers. The Journal of Business \& Industrial Marketing, 9(3), 44.

de Boer, L.H., Elsebeth; Pop-Sitar, Corina. (2003). Purchasing as an organizational design problem: The case of non-product-related items and services. Management Decision, 41(9), 911-922.

De Toni, A.N., Guido; Tonchia, Stefano. (1994). Service dimensions in the buyer-supplier relationship: A case study. International Journal of Physical Distribution \& Logistics Management, 24(8), 4.

Degraeve, Z., Labro, E., \& Roodhooft, F. (2004). Total cost of ownership purchasing of a service: The case of airline selection at Alcatel Bell. European Journal of Operational Research, 156(1), 23-40.

Dobrzykowski, D.D., Hong, P., Hong, P.C., \& Soon Park, J. (2012). Building procurement capability for firm performance: a service-dominant logic view. Benchmarking: An International Journal, 19(4/5), 567-584.

Doran, D., Thomas, P., \& Caldwell, N. (2005). Examining buyer-supplier relationships within a service sector context. Supply Chain Management: An International Journal, 10(4), 272-277.

Ellram, L., \& Tate, W.L. (2015). Redefining supply management's contribution in services sourcing. Journal of Purchasing and Supply Management, 21(1), 64-78.

Espino-Rodríguez, T.F., Lai, P.C., \& Baum, T. (2008). Asset specificity in make or buy decisions for service operations. International Journal of Service Industry Management, 19(1), 111-133.

Esteve-González, P. (2016). Moral hazard in repeated procurement of services. International Journal of Industrial Organization, 48, 244-269.

Evans, K.R.F., Howard D.; Foster, Jerry. (1990). Purchasing Motor Carrier Service: An Investigation of the Criteria Used by Small Manufacturing Firms. Journal of Small Business Management, 28(1), 39.

Everaert, P., Sarens, G., \& Rommel, J. (2007). Sourcing strategy of Belgian SMEs: empirical evidence for the accounting services. Production Planning \& Control, 18(8), 716-725.

Ferguson, W. (1983). Buying an industrial service warehouse space. Industrial Marketing Management, 12(1), 63-66.

Francis, W.H.Y., Joseph, H.K.L., \& Yuen, P.L. (2012). Impacts of facility service procurement methods on perceived performance of hospital engineering services. Facilities, 30(1/2), 56-77. 
Fredendall, L.D., Hopkins, C.D., \& Bhonsle, A. (2005). Purchasing's Internal Service Performance: Critical External and Internal Determinants. Journal of Supply Chain Management, 41(2), 26-38.

Fulconis, F., Nollet, J., \& Paché, G. (2016). Purchasing of logistical services: a new view of LSPs' proactive strategies. European Business Review, 28(4), 449-466.

Geisler, E.H., Wen. (1992). Purchasing Information Technologies: Behavior Patterns in Service Companies. International Journal of Purchasing and Materials Management, 28(3), 38-42.

Gelderman, C.J., Semeijn, J., \& de Bruijn, A. (2015). Dynamics of service definitions-An explorative case study of the purchasing process of professional ICTservices. Journal of Purchasing and Supply Management, 21(3), 220-227.

Gibson, B.J.M., R. A.; Sink, H. L. (1995). Supplier certification-Application to the purchase of industrial transportation services. Logistics and Transportation Review, 31(1), 63-74.

Gligor, D.M., \& Holcomb, M. (2013). The role of personal relationships in supply chains. The International Journal of Logistics Management, 24(3), 328-355.

Gomes, M., Fernandes, T., \& Brandão, A. (2016). Determinants of brand relevance in a B2B service purchasing context. Journal of Business \& Industrial Marketing, 31(2), 193-204.

Grudinschi, D., Sintonen, S., \& Hallikas, J. (2014). Relationship risk perception and determinants of the collaboration fluency of buyer-supplier relationships in public service procurement. Journal of Purchasing and Supply Management, 20(2), 82-91.

Guercini, S.R., Silvia. (2015). Buyer-seller interaction in facility services. Journal of Service Theory and Practice, 25(2), 162-180.

Hallikas, J., Immonen, M., Pynnönen, M., \& Mikkonen, K. (2014). Service purchasing and value creation: Towards systemic purchases. International Journal of Production Economics, 147, 53-61.

Hansson, L.H., Johan. (2011). Bypassing Public Procurement Regulation: A Study of Rationality in Local Decisionmaking. Regulation and Governance, 5(3), 368-385.

Hawkins, T.G., Gravier, M.J., Berkowitz, D., \& Muir, W.A. (2015). Improving services supply management in the defense sector: How the procurement process affects B2B service quality. Journal of Purchasing and Supply Management, 21(2), 81-94.

Holmlund, M., \& Kock, S. (1995). Buyer perceived service quality in industrial networks. Industrial Marketing Management, 24(2), 109-121.

Holmlund, M., Kowalkowski, C., \& Biggemann, S. (2016). Organizational behavior in innovation, marketing, and purchasing in business service contexts-An agenda for academic inquiry. Journal of Business Research, 69(7), 2457-2462.

Holschbach, E., \& Hofmann, E. (2011). Exploring quality management for business services from a buyer's perspective using multiple case study evidence. International Journal of Operations \& Production Management, 31(6), 648-685.

Holter, A.R., Halldórsson, Á., Grant, D.B., Ritchie, J., \& Shaw, N. (2008). A framework for purchasing transport services in small and medium size 
enterprises. International Journal of Physical Distribution \& Logistics Management, 38(1), 21-38.

Immonen, M., Hallikas, J., \& Pynnönen, M. (2016). Antecedents of system purchasing in B2B services. Journal of Purchasing and Supply Management, 22(3), 205-213.

Jackson, R.W., Neidell, L.A., \& Lunsford, D.A. (1995). An empirical investigation of the differences in goods and services as perceived by organizational buyers. Industrial Marketing Management, 24(2), 99-108.

Jamalzadeh, R., Ardehali, M.M., \& Rashidinejad, M. (2008). Development of modified rational buyer auction for procurement of ancillary services utilizing participation matrix. Energy Policy, 36(2), 900-909.

Jensen, P.D.Ø., \& Petersen, B. (2013). Global Sourcing of Services: Risk, Process, and Collaborative Architecture. Global Strategy Journal, 3(1), 67-87.

Johnston, W.J., \& Bonama, T.V. (1981). Purchase process for capital equipment and services. Industrial Marketing Management, 10(4), 253-264.

Jones, E., Busch, P., \& Dacin, P. (2003). Firm market orientation and salesperson customer orientation: interpersonal and intrapersonal influences on customer service and retention in business-to-business buyer-seller relationships. Journal of Business Research, 56(4), 323-340.

Jothi Basu, R., Bai, R., \& Palaniappan, P.K. (2015). A strategic approach to improve sustainability in transportation service procurement. Transportation Research Part E: Logistics and Transportation Review, 74, 152-168.

Kadefors, A., Björlingson, E., \& Karlsson, A. (2007). Procuring service innovations: Contractor selection for partnering projects. International Journal of Project Management, 25(4), 375-385.

Kotabe, M., \& Murray, J.Y. (2004). Global procurement of service activities by service firms. International Marketing Review, 21(6), 615-633.

Kotabe, M.M., Janet Y.; Javalgi, Rajshekhar G. (1998). Global sourcing of services and market performance: An empirical investigation. Journal of International Marketing, 6(4), 10-31.

Large, R.O., \& König, T. (2009). A gap model of purchasing's internal service quality: Concept, case study and internal survey. Journal of Purchasing and Supply Management, 15(1), 24-32.

Large, R.O., Kramer, N., \& Hartmann, R.K. (2013). Procurement of logistics services and sustainable development in Europe: Fields of activity and empirical results. Journal of Purchasing and Supply Management, 19(3), 122-133.

Lee, Y.-W., \& Bellman, S. (2008). An Augmented Model of Customer Loyalty for Organizational Purchasing of Financial Services. Journal of Business-to-Business Marketing, 15(3), 290-322.

Leek, S., Turnbull, P.W., \& Naudé, P. (2004). A comparison of manufacturers and financial services suppliers' and buyers' use of relationship management methods. Industrial Marketing Management, 33(3), 241-249.

Lian, P.C., \& Laing, A.W. (2004). The role of professional expertise in the purchasing of health services. Health Services Management Research, 17(2), $110-120$. 
Lian, P.C.S., \& Laing, A.W. (2004). Public sector purchasing of health services: A comparison with private sector purchasing. Journal of Purchasing and Supply Management, 10(6), 247-256.

Lian, P.C.S., \& Laing, A.W. (2007). Relationships in the purchasing of business to business professional services: The role of personal relationships. Industrial Marketing Management, 36(6), 709-718.

Lindberg, N., \& Nordin, F. (2008). From products to services and back again: Towards a new service procurement logic. Industrial Marketing Management, 37(3), 292-300.

Martin, J.H., Daley, J.M., \& Burdg, H.B. (1988). Buying influences and perceptions of transportation services. Industrial Marketing Management, 17(4), 305-314.

Mawson, E., \& Fearne, A. (1996). Purchasing strategies and decision-making processes in the food service industry: a case study of UK restaurant chains. Supply Chain Management: An International Journal, 1(3), 34-41.

Merkert, R., \& O'Fee, B. (2013). Efficient procurement of public air servicesLessons learned from European transport authorities' perspectives. Transport Policy, 29, 118-125.

Mitchell, V.W., Moutinho, L., \& Lewis, B.R. (2003). Risk Reduction in Purchasing Organisational Professional Services. The Service Industries Journal, 23(5), $1-19$.

Money, R.B. (2000). Word-of-mouth referral sources for buyers of international corporate financial services. Journal of World Business, 35(3), 314-329.

Money, R.B., Gilly, M.C., \& Graham, J.L. (1998). Explorations of National Culture and Word-of-Mouth Referral Behavior in the Purchase of Industrial Services in the United States and Japan. Journal of Marketing, 62(4), 76.

Murray, J.Y., \& Kotabe, M. (1999). Sourcing strategies of U.S. service companies: a modified transaction-cost analysis. Strategic Management Journal, 20(9), 791-809.

Murray, J.Y.K., M.; Westjohn, S. A. (2009). Global Sourcing Strategy and Performance of Knowledge-Intensive Business Services: A Two-Stage Strategic Fit Model. Journal of International Marketing, 17(4), 90-105.

Nayyar, P.R. (1990). Information asymmetries: A source of competitive advantage for diversified service firms. Strategic Management Journal, 11(7), 513-519.

Newton, D.A. (1965). Advertising agency services: make or buy? Harvard Business Review, 43(4), 111-118.

Nordin, F. (2008). Linkages between service sourcing decisions and competitive advantage: A review, propositions, and illustrating cases. International Journal of Production Economics, 114(1), 40-55.

Pardos, E., Gómez-Loscos, A., \& Rubiera-Morollón, F. (2007). 'Do versus Buy' Decisions in the Demand for Knowledge Intensive Business Services. The Service Industries Journal, 27(3), 233-249.

Pemer, F., Sieweke, J., Werr, A., Birkner, S., \& Mohe, M. (2014). The cultural embeddedness of professional service purchasing - A comparative study of German and Swedish companies. Journal of Purchasing and Supply Management, 20(4), $273-285$. 
Pemer, F., Werr, A., \& Bianchi, M. (2014). Purchasing professional services: A transaction cost view of the antecedents and consequences of purchasing formalization. Industrial Marketing Management, 43(5), 840-849.

Perreault, W.D., \& Russ, F.A. (1976). Physical Distribution Service in Industrial Purchase Decisions. Journal of Marketing, 40(2), 3.

Perrone, G., Roma, P., \& Lo Nigro, G. (2010). Designing multi-attribute auctions for engineering services procurement in new product development in the automotive context. International Journal of Production Economics, 124(1), 20-31.

Radkevitch, U., van Heck, E., \& Koppius, O. (2009). Portfolios of buyer-supplier exchange relationships in an online marketplace for IT services. Decision Support Systems, 47(4), 297-306.

Roth, M.S., Money, R.B., \& Madden, T.J. (2004). Purchasing processes and characteristics of industrial service buyers in the U.S. and Japan. Journal of World Business, 39(2), 183-198.

Saleh, F.A., \& Sarkar, A.K. (1973). Marketing of professional services: An analysis of the buyer selection systems. Industrial Marketing Management, 3(1), 15-23.

Schiele, J.J. (2005). Meaningful involvement of municipal purchasing departments in the procurement of consulting services: Case studies from Ontario, Canada. Journal of Purchasing and Supply Management, 11(1), 14-27.

Schiele, J.J.M., Clifford P. (2006). Professional service acquisition in public sector procurement: A conceptual model of meaningful involvement. International Journal of Operations \& Production Management, 26(3/4), 300-325.

Schlesinger, M., Dorwart, R.A., \& Pulice, R.T. (1986). Competitive bidding and states' purchase of services: the case of mental health care in Massachusetts. Journal of Policy Analysis and Management, 5(2), 245-263.

Selviaridis, K., Agndal, H., \& Axelsson, B. (2011). Business services 'in the making': (De)Stabilisation of service definitions during the sourcing process. Journal of Purchasing and Supply Management, 17(2), 73-86.

Sharma, D.D. (1994). Classifying buyers to gain marketing insight: A relationships approach to professional services. International Business Review, 3(1), 15-30.

Sheffi, Y. (2004). Combinatorial Auctions in the Procurement of Transportation Services. Interfaces, 34(4), 245-252.

Smeltzer, L.R.O., Jeffrey A. (2002). Purchasing professionals' perceived differences between purchasing materials and purchasing services. Journal of Supply Chain Management, 38(1), 54-70.

Sonmez, M., \& Moorhouse, A. (2010). Purchasing professional services: which decision criteria? Management Decision, 48(2), 189-206.

Stanley, L.L., \& Wisner, J.D. (2001). Service quality along the supply chain: implications for purchasing. Journal of Operations Management, 19(3), 287-306.

Stanley, L.L., \& Wisner, J.D. (2002). The determinants of service quality: issues for purchasing. European Journal of Purchasing \& Supply Management, 8(2), 97-109.

Stock, J.R., \& Zinszer, P.H. (1987). The industrial purchase decision for professional services. Journal of Business Research, 15(1), 1-16.

Stremersch, S., Wuyts, S., \& Frambach, R.T. (2001). The Purchasing of Full-Service Contracts. Industrial Marketing Management, 30(1), 1-12. 
Tate, W.L., Ellram, L.M., Bals, L., Hartmann, E., \& van der Valk, W. (2010). An Agency Theory perspective on the purchase of marketing services. Industrial Marketing Management, 39(5), 806-819.

Turnbull, P.W. (1982). The Purchasing of International Financial Services by Medium- and Large-Sized UK Companies with European Subsidiaries. European Journal of Marketing, 16(3), 111-121.

van der Valk, W. (2008). Service procurement in manufacturing companies: Results of three embedded case studies. Industrial Marketing Management, 37(3), 301-315.

van der Valk, W., \& Rozemeijer, F. (2009). Buying business services: towards a structured service purchasing process. Journal of Services Marketing, 23(1), $3-10$.

van der Valk, W., \& van Iwaarden, J. (2011). Monitoring in service triads consisting of buyers, subcontractors and end customers. Journal of Purchasing and Supply Management, 17(3), 198-206.

van der Valk, W., \& Wynstra, F. (2012). Buyer-supplier interaction in business-to-business services: A typology test using case research. Journal of Purchasing and Supply Management, 18(3), 137-147.

van der Valk, W., \& Wynstra, F. (2014). Variety in business-to-business services and buyer-supplier interaction. International Journal of Operations \& Production Management, 34(2), 195-220.

van der Valk, W., Wynstra, F., \& Axelsson, B. (2009). Effective buyer-supplier interaction patterns in ongoing service exchange. International Journal of Operations \& Production Management, 29(8), 807-833.

van Hoek, R.I. (2000). The purchasing and control of supplementary thirdparty logistics services. Journal of Supply Chain Management, 36(4), 14-26.

van Mossel, H.-J., \& van der Valk, W. (2008). Securing customer satisfaction through component service specifications. Journal of Purchasing and Supply Management, 14(4), 241-252.

Werr, A., \& Pemer, F. (2007). Purchasing management consulting servicesFrom management autonomy to purchasing involvement. Journal of Purchasing and Supply Management, 13(2), 98-112.

West, D.C. (1997). Purchasing professional services: The case of advertising agencies. International Journal of Purchasing and Materials Management, 33(3), 2-9.

Wittreich, W.J. (1966). How to buy/sell professional services. Harvard Business Review, 44(2), 127-138.

Wolf, C., Halldórsson, Á., \& Seuring, S. (2010). Environmental impacts as buying criteria for third party logistical services. International Journal of Physical Distribution \& Logistics Management, 40(1/2), 84-102.

Woodside, A.G., Wilson, E.J., \& Milner, P. (1992). Buying and marketing CPA services. Industrial Marketing Management, 21(3), 265-272.

Wynstra, F., Axelsson, B., \& van der Valk, W. (2006). An application-based classification to understand buyer-supplier interaction in business services. International Journal of Service Industry Management, 17(5), 474-496. 
Yang, Z.B., Volodymyr. (2015). Does a Procurement Service Provider Generate Value for the Buyer through Information about Supply Risks? Management Science, 61(5), 979-998.

Yoon, E., Guffey, H.J., \& Kijewski, V. (1993). The effects of information and company reputation on intentions to buy a business service. Journal of Business Research, 27(3), 215-228.

Zhang, B., Ding, H., Li, H., Wang, W., \& Yao, T. (2013). A Sampling-Based Stochastic Winner Determination Model for Truckload Service Procurement. Networks and Spatial Economics, 14(2), 159-181.

Zimmermann, S., Müller, M., \& Heinrich, B. (2016). Exposing and selling the use of web services-an option to be considered in make-or-buy decision-making. Decision Support Systems, 89, 28-40.

Zinszer, P.H. (1997). Segmenting logistical service offerings using the extended buygrid model. International Journal of Physical Distribution \& Logistics Management, 27(9/10), 588-599.

\section{Appendix 2: Extended list of most co-cited literature in the corpus}

\begin{tabular}{|c|c|c|}
\hline Publication & Cluster $\left[{ }^{*}\right]$ & $\begin{array}{l}\text { Contribution to the business service purchasing } \\
\text { literature }\end{array}$ \\
\hline Axelsson and Wynstra (2002) & 1 & $\begin{array}{l}\text { Comprehensive book that defines the characteristics } \\
\text { of various services in the context of organizational } \\
\text { networks and the purchasing function }\end{array}$ \\
\hline Eisenhardt (1989) & 1 & $\begin{array}{l}\text { Academic article, which assesses the agency } \\
\text { theory and how it can be used for organizational } \\
\text { researchers to explain processes like a make-or-buy } \\
\text { decision }\end{array}$ \\
\hline Ellram et al. (2008) & 1 & $\begin{array}{l}\text { Academic article, which applies a transaction cost } \\
\text { theory (specifically transaction cost economics) } \\
\text { framework for understanding the costs and risks of } \\
\text { companies in the process of outsourcing profes- } \\
\text { sional services. References the works of William- } \\
\text { son (1975) }\end{array}$ \\
\hline van der Valk and Rozemeijer (2009) & 1 & $\begin{array}{l}\text { The article develops an eight-step process for the } \\
\text { purchasing of business services and includes points } \\
\text { from the service-dominant logic of Vargo and } \\
\text { Lusch (2004). The process is an extension of the } \\
\text { purchasing process by Van Weele (2005) }\end{array}$ \\
\hline Voss et al. (2002) & 1 & $\begin{array}{l}\text { Article on how and when to use case study research } \\
\text { in the context of operations management, which } \\
\text { references Eisenhardt (1989). The primary aim is to } \\
\text { develop and test new theories }\end{array}$ \\
\hline Wynstra et al. (2006) & 1 & $\begin{array}{l}\text { Conceptual paper that establishes a classification of } \\
\text { business services from the viewpoint of the buying } \\
\text { company. The emphasis lies on the interaction pro- } \\
\text { cess between buyers and suppliers after purchasing. } \\
\text { Expands on the work of Jackson et al. (1995) }\end{array}$ \\
\hline
\end{tabular}


Publication Cluster [*] Contribution to the business service purchasing literature

Ellram et al. (2004)

Fitzsimmons et al. (1998b)

Håkansson (1982)

Cox (1996)

2

\section{Article highlights the relevance of service purchasing for a company, with the intent of developing a sup- ply chain framework fitting for services. Assesses and combines the manufacturing models of the Global Supply Chain Forum Framework, SCOR and HewlettPackard's Supply Chain Management Model}

Article develops a taxonomy for business service purchasing with two dimensions (importance of service and focus of the service). For each of the six resulting classifications implications for managers are explored. Expands with a focus on the business process the works of Lovelock (1983)

Book that proposes that the purchasing function is essentially the management of buyer-seller relationships. Combines Interorganizational theory and the New Institutional Economic theory to an interaction model

Empirical article, which collects the different challenges an organizational buyer in the marketing of goods and services faces. The differences are described on six latent dimensions. Agrees with Lovelock (1983) and puts certain findings of Parasuraman et al. (1985) in question

2 Conceptual article that develops five interlinked classifications schemes for the marketing of services. The goal was to help managers better understand their business and to transcend the narrow industry thinking

Article that develops an eight-step decision process for the purchasing of consultancy services. The focus is to highlight the difficulties and risks associated with the management of consultancy services

Exploratory article that develops the SERVQUALmodel to measure the quality of consumer services

Empirical article that explores the exact differences between services and goods on 15 process steps based on the purchasing of goods. There is a call for more research in the area of business services from the buyer's perspective. Picks up points both from Lovelock (1983) and Mitchell (1994)

This article focuses on the purchasing of advertising services from the provider perspective and names intangibility as the biggest challenge. Advocates for a strong purchasing position

Added [**] Article tries to provide a theoretical clarification of the optimal role for procurement within business management based on the transaction theory of Williamson (1975). Argues that a strategic approach to procurement has to be adopted for successful firms 


\begin{tabular}{lcl}
\hline Publication & Cluster [*] & $\begin{array}{l}\text { Contribution to the business service purchasing } \\
\text { literature }\end{array}$ \\
\hline Williamson (1975) & Added [**] $\begin{array}{l}\text { Proposes transactions as the basic unit of analysis for } \\
\text { understanding firms and markets. Joins econom- } \\
\text { ics, organizational theory and aspect of contract } \\
\text { law. Firms become through this view a nexus of } \\
\text { contracts } \\
\text { Grönroos (2000) }\end{array}$ \\
& $\begin{array}{l}\text { Added [**al marketing book, which establishes that } \\
\text { services exchanges are interactive processes, where } \\
\text { both the seller and the buyer parties are involved in } \\
\text { production and consumption of the product }\end{array}$
\end{tabular}

[*] Clustered according to co-citation analysis in VosViewer

[**] Added through an author co-citation analysis

\section{Appendix 3: Short explanation of theories with at least two related publications}

\begin{tabular}{|c|c|c|}
\hline Theory & Mentions & Use in context of business service purchasing \\
\hline Transaction cost theory & 11 & $\begin{array}{l}\text { The service purchasing firm and the seller have an inter- } \\
\text { organizational relationship, which is based "on opportunism } \\
\text { and bounded rationality". The core goal for both parties in } \\
\text { this exchange is to minimize costs (Rossignoli and Ricciardi } \\
2015, \text { p. 7). Based on the writings of Williamson (1975) }\end{array}$ \\
\hline Agency theory & 5 & $\begin{array}{l}\text { The service purchasing firm and the seller have an inter- } \\
\text { organizational relationship, which is based "on opportunism } \\
\text { and bounded rationality". The core goal for both parties in } \\
\text { this exchange is align the "behaviors or outcomes of the } \\
\text { other parties to expectations" (Rossignoli and Ricciardi } \\
\text { 2015, p. 7). Based on the writings of Eisenhardt (1989) }\end{array}$ \\
\hline Auction theory & 5 & $\begin{array}{l}\text { In the auction process of a service buying firm a game theory } \\
\text { optimization approach is taken. The buyer firm optimizes } \\
\text { the total expenditures in this process (Sheffi 2004, p. 247). } \\
\text { First applied by Vickrey (1961) }\end{array}$ \\
\hline Service marketing theory & 4 & $\begin{array}{l}\text { Fuzzy theory that concerns itself with understanding the } \\
\text { "generic features of the professional service" to lay the } \\
\text { groundwork for an optimal marketing process (Gummesson } \\
\text { 1978). Authors to consider are Grönroos (1982), Gummes- } \\
\text { son (1978) and Chase and Erikson (1988). Today closely } \\
\text { linked to the service-dominant logic of Vargo and Lusch } \\
\text { (2004) }\end{array}$ \\
\hline Organizational buying theory & 4 & $\begin{array}{l}\text { Theory that sees the B2B purchasing as a "decision-making } \\
\text { process carried out by individuals, in interaction with other } \\
\text { people, in the context of a formal organization" (Webster Jr. } \\
\text { and Wind 1972, p. 12). Started with the writings of Webster } \\
\text { Jr. and Wind (1972), which today encompasses a myriad of } \\
\text { topics like word of mouth effects e.g. West (1997) }\end{array}$ \\
\hline
\end{tabular}




\begin{tabular}{|c|c|c|}
\hline Theory & Mentions & Use in context of business service purchasing \\
\hline Contingency theory & 2 & $\begin{array}{l}\text { Theory states that there is no one-size-fits all for service } \\
\text { procurement organizations, and companies have to align } \\
\text { their strategy with the specific environment (Murray et al. } \\
2009 \text {, p. 93). Originally from the leadership literature from } \\
\text { Fiedler (1964) }\end{array}$ \\
\hline Contract theory & 2 & $\begin{array}{l}\text { High-level theory, which is mainly concerned with the } \\
\text { contract and the main interest are incentives for the parties } \\
\text { involved. Incorporates "moral hazard problem"-aspects and } \\
\text { is closely related to the transaction theory and agent theory } \\
\text { (Esteve-González } 2016, \text { p. } 247 \text { ) }\end{array}$ \\
\hline Qualification theory & 2 & $\begin{array}{l}\text { Theory that rejects the notion that exchanged services can } \\
\text { have a "stable" definition. Services have a temporally } \\
\text { constellation of characteristics to allow trading (Selviaridis } \\
\text { et al. 2011, p. } 75 \text { ). Manly proposed in the service purchas- } \\
\text { ing context by Selviaridis et al. (2011) based on the writings } \\
\text { of Gadrey (2000) }\end{array}$ \\
\hline Social exchange theory & 2 & $\begin{array}{l}\text { Theory used to understand the behavior of sales persons, } \\
\text { which "reciprocate or imitate" the conduct of the buyer. } \\
\text { This is based on the writings of Adams (1965) with the } \\
\text { basic idea that "individuals engage in reciprocal behaviors } \\
\text { and support those who provide benefits" (Jones et al. 2003, } \\
\text { p. 326) }\end{array}$ \\
\hline
\end{tabular}

\section{References}

Adams JS (1965) Inequity in social exchange. In: Advances in experimental social psychology, vol 2, pp 267-299. Elsevier, Amsterdam. https://doi.org/10.1016/S0065-2601(08)60108-2

Agndal H, Axelsson B, Lindberg N, Nordin F (2007) Trends in service sourcing practices. J Bus Market Manag 1(3):187-208

Ancarani A, Capaldo G (2005) Supporting decision-making process in facilities management services procurement: a methodological approach. J Purch Supply Manag 11(5-6):232-241. https://doi. org/10.1016/j.pursup.2005.12.004

Axelsson B, Wynstra F (2002) Buying business services. Wiley, Hoboken

Bals L, Hartmann E, Ritter T (2009) Barriers of purchasing departments' involvement in marketing service procurement. Ind Mark Manag 38(8):892-902. https://doi.org/10.1016/j.indma rman.2009.06.010

Bardsley P, Burfurd I (2013) Auctioning contracts for environmental services. Aust J Agric Resource Econ 57(2):253-272

Benjamin O, Nisim S, Segev G (2014) Corporate social responsibility as shaped by managers' role dissonance: cleaning services procurement in Israel. J Bus Ethics 130(1):209-221. https://doi. org/10.1007/s10551-014-2213-9

Boddewyn JJ, Soehl R, Picard J (1986) Standardization in international marketing: is Ted Levitt in fact right? Bus Horiz 29(6):69-75

Boote DN, Beile P (2005) Scholars before researchers: on the centrality of the dissertation literature review in research preparation. Educ Res 34(6):3-15

Brundtland Commission (1987) Report of the world commission on environment and development: our common future, transmitted to the United Nations General Assembly as an annex to document A/42/427. Development and International Co-operation: Environment

Bryntse K (1996) The purchasing of public services exploring the purchasing function in a service context. Eur J Purch Supply Manag 2(4):193-201. https://doi.org/10.1016/s0969-7012(96)00015-9 
Bustinza O, Parry G, Vendrell-Herrero F (2013) Supply and demand chain management: the effect of adding services to product offerings. Supply Chain Manag Int J 18(6):618-629

Caldwell ND, Roehrich JK, Davies AC (2009) Procuring complex performance in construction: London heathrow terminal 5 and a private finance initiative hospital. J Purch Supply Manag 15(3):178-186

Caplice C, Sheffi Y (2003) Optimization-based procurement for transport services. J Bus Logist 24(2):109-128

Carter C, Ellram L (2003) Thirty-Rve years of the journal of supply chain management: where have we been and where are we going? J Supply Chain Manag 39(1):27-39

Chase RB, Erikson WJ (1988) The service factory. Acad Manag Exec 2(3):191-196

Cox A (1996) Relational competence and strategic procurement management: towards an entrepreneurial and contractual theory of the firm. Eur J Purch Supply Manag 2(1):57-70

Cox A, Chicksand D, Ireland P, Davies T (2005) Sourcing indirect spend: a survey of current internal and external strategies for non-revenue-generating goods and services. J Supply Chain Manag 41(2):39-51

Cox A, Chicksand D, Yang T (2007) The proactive alignment of sourcing with marketing and branding strategies: a food service case. Supply Chain Manag Int J 12(5):321-333. https://doi. org/10.1108/13598540710776908

D'Emidio T, Dorton D, Duncan E (2015) Service innovation in a digital world. McKinsey Q 1-8

Darnall N, Stritch JM, Bretschneider S, Hsueh L, Duscha M, Iles J et al (2017) Advancing green purchasing in local governments. Retrieved from Phoenix

Day E, Barksdale HC Jr (1994) Organizational purchasing of professional services: the process of selecting providers. J Bus Ind Mark 9(3):44

Dobrzykowski DD, Hong PC, Park JS (2012) Building procurement capability for firm performance: a service-dominant logic view. Benchmarking 19(4/5):567-584. https://doi.org/10.1108/1463577121 1258016

Eggert A, Hogreve J, Ulaga W, Muenkhoff E (2014) Revenue and profit implications of industrial service strategies. J Serv Res 17(1):23-39

Eisenhardt KM (1989) Agency theory: an assessment and review. Acad Manag Rev 14(1):57-74

Elkington J (2002) The triple bottom line. In

Ellram L, Tate W (2015) Redefining supply management's contribution in services sourcing. J Purch Supply Manag 21(1):64-78. https://doi.org/10.1016/j.pursup.2014.10.001

Ellram L, Tate W, Billington C (2004) Understanding and managing the services supply chain. J Supply Chain Manag 40(3):17-32

Ellram L, Tate W, Billington C (2008) Offshore outsourcing of professional services: a transaction cost economics perspective. J Oper Manag 26(2):148-163. https://doi.org/10.1016/j.jom.2007.02.008

Espino-Rodríguez TF, Lai PC, Baum T (2008) Asset specificity in make or buy decisions for service operations. Int J Serv Ind Manag 19(1):111-133. https://doi.org/10.1108/09564230810855734

Esteve-González P (2016) Moral hazard in repeated procurement of services. Int J Ind Organ 48:244269. https://doi.org/10.1016/j.ijindorg.2016.06.008

Fahimnia B, Tang CS, Davarzani H, Sarkis J (2015) Quantitative models for managing supply chain risks: a review. Eur J Oper Res 247(1):1-15

Fiedler FE (1964) A contingency model of leadership effectiveness. In: Advances in experimental social psychology, vol 1, pp 149-190. Elsevier

Fitzsimmons J, Noh J, Thies E (1998a) Purchasing business services. J Bus Ind Mark 13(4/5):370-380

Fitzsimmons JA, Noh J, Thies E (1998b) Purchasing business services. J Bus Ind Mark 13(4/5):370-380

Fleisch E, Weinberger M, Wortmann F (2015) Business models and the internet of things (Extended Abstract). In: Podnar Žarko I, Pripužić K, Serrano M (eds) Interoperability and open-source solutions for the internet of things. Springer, Cham, pp 6-10. https://doi.org/10.1007/978-3-319-16546 $-2 \_2$

Fredendall L, Hopkins C, Bhonsle A (2005) Purchasing's internal service performance: critical external and internal determinants. J Supply Chain Manag 41(2):26-38

Fulconis F, Nollet J, Pache G (2016) Purchasing of logistical services: a new view of LSPs' proactive strategies. Eur Bus Rev 28(4):449-466. https://doi.org/10.1108/ebr-06-2015-0054

Gadrey J (2000) The characterization of goods and services: an alternative approach. Rev Income Wealth 46(3):369-387

Gaiardelli P, Songini L, Saccani N (2014) The automotive industry: heading towards servitization in turbulent times. In: Servitization in industry, pp 55-72. Springer 
Geisler E, Hoang W (1992) Purchasing information technologies: behavior patterns in service companies. Int J Purch Mater Manag 28(3):38

Gelderman CJ, Semeijn J, de Bruijn A (2015) Dynamics of service definitions: an explorative case study of the purchasing process of professional ICT-services. J Purch Supply Manag 21(3):220-227. https://doi.org/10.1016/j.pursup.2015.04.004

Gligor DM, Holcomb M (2013) The role of personal relationships in supply chains. Int J Logist Manag 24(3):328-355. https://doi.org/10.1108/ijlm-07-2012-0067

Grönroos C (1984) A service quality model and its marketing implications. Eur J Mark 18(4):36-44

Grönroos C (2000) Service management and marketing: a customer relationship management approach. Wiley, Chichester

Grönroos C (2009) Marketing as promise management: regaining customer management for marketing. J Bus Ind Mark 24(5/6):351-359

Guercini S, Ranfagni S (2015) Buyer-seller interaction in facility services. J Serv Theory Pract 25(2):162-180

Gummesson E (1978) Toward a theory of professional service marketing. Ind Mark Manag 7(2):89-95

Gupta A (2013) Environment \& PEST analysis: an approach to the external business environment. Int J Mod Soc Sci 2(1):34-43

Håkansson H (1982) Industrial marketing and purchasing of industrial goods: an interaction approach. Wiley, New York

Hänsel M, Hofmann E (2016) Evaluation of business services from a buyer's perspective: the place of consumption as distinctive feature. In: Paper presented at the RIRL 2016-international meeting on logistics research (07-09.09.2016), Lausanne

Hänsel M, Hofmann E (2017) Evaluation of business services from a buyer's perspective: the service type as a distinctive feature. Supply Chain Forum: Int J 18(4):240-248

Hansson L, Holmgren J (2011) Bypassing public procurement regulation: a study of rationality in local decisionmaking. Regul Gov 5(3):368-385

Harland C, Lamming R, Walker H, Phillips W, Caldwell N, Johnsen T, Zheng J (2006) Supply management: is it a discipline? Int J Oper Prod Manag 26(7):730-753

Hawkins TG, Gravier MJ, Berkowitz D, Muir WA (2015) Improving services supply management in the defense sector: how the procurement process affects B2B service quality. J Purch Supply Manag 21(2):81-94. https://doi.org/10.1016/j.pursup.2014.12.007

Hoejmose SU, Adrien-Kirby AJ (2012) Socially and environmentally responsible procurement: a literature review and future research agenda of a managerial issue in the 21 st century. J Purch Supply Manag 18(4):232-242

Hofmann E, Rüsch M (2017) Industry 4.0 and the current status as well as future prospects on logistics. Comput Ind 89:23-34

Hofmann E, Hänsel M, Vollrath C (2016) The purchasing of business services - performance excellence study 2016, vol 1. Cuvillier Verlag, Göttingen. https://cuvillier.de/de/shop/publications/7428-thepurchasing-of-business-services

Holmlund M, Kowalkowski C, Biggemann S (2016) Organizational behavior in innovation, marketing, and purchasing in business service contexts: an agenda for academic inquiry. J Bus Res 69(7):2457-2462. https://doi.org/10.1016/j.jbusres.2016.02.014

Holschbach E (2013) Comparison of quality management for externally sourced business services. Int J Qual Reliab Manag 30(5):530-570

Holschbach E, Hofmann E (2011) Exploring quality management for business services from a buyer's perspective using multiple case study evidence. Int J Oper Prod Manag 31(6):648-685. https://doi. org/10.1108/01443571111131980

Holter AR, Halldórsson Á, Grant DB, Ritchie J, Shaw N (2008) A framework for purchasing transport services in small and medium size enterprises. Int J Phys Distrib Logist Manag 38(1):21-38. https ://doi.org/10.1108/09600030810857193

Horvath L (2001) Collaboration: the key to value creation in supply chain management. Supply Chain Manag Int J 6(5):205-207

Jackson RW, Neidell LA, Lunsford DA (1995) An empirical investigation of the differences in goods and services as perceived by organizational buyers. Ind Mark Manag 24(2):99-108. https://doi. org/10.1016/0019-8501(94)00037-W

Jamalzadeh R, Ardehali MM, Rashidinejad M (2008) Development of modified rational buyer auction for procurement of ancillary services utilizing participation matrix. Energy Policy 36(2):900-909. https://doi.org/10.1016/j.enpol.2007.11.010 
Jinha AE (2010) Article 50 million: an estimate of the number of scholarly articles in existence. Learn Publ 23(3):258-263

Jones E, Busch P, Dacin P (2003) Firm market orientation and salesperson customer orientation: interpersonal and intrapersonal influences on customer service and retention in business-to-business buyerseller relationships. J Bus Res 56(4):323-340. https://doi.org/10.1016/s0148-2963(02)00444-7

Jothi Basu R, Bai R, Palaniappan PK (2015) A strategic approach to improve sustainability in transportation service procurement. Transp Res E: Logist Transp Rev 74:152-168. https://doi.org/10.1016/j. tre.2014.10.015

Kim S-H, Cohen MA, Netessine S (2007) Performance contracting in after-sales service supply chains. Manag Sci 53(12):1843-1858

Kotabe M, Murray JY (2004) Global procurement of service activities by service firms. Int Mark Rev 21(6):615-633

Large RO, König T (2009) A gap model of purchasing's internal service quality: concept, case study and internal survey. J Purch Supply Manag 15(1):24-32. https://doi.org/10.1016/j.pursup.2008.10.001

Levitt T (1983) The globalization of markets. Harvard Business Review, 61 May-June, pp 92-102

Lian PCS, Laing AW (2007) Relationships in the purchasing of business to business professional services: the role of personal relationships. Ind Mark Manag 36(6):709-718. https://doi.org/10.1016/j. indmarman.2006.05.004

Lightfoot H, Baines T, Smart P (2013) The servitization of manufacturing: a systematic literature review of interdependent trends. Int J Oper Prod Manag 33(11/12):1408-1434

Lindberg N, Nordin F (2008) From products to services and back again: towards a new service procurement logic. Ind Mark Manag 37(3):292-300. https://doi.org/10.1016/j.indmarman.2007.07.006

Lovelock CH (1983) Classifying services to gain strategic marketing insights. J Mark 47:9-20

Marciniak R (2014) Global shared service trends in the central and eastern European markets. Entrep Bus Econ Rev 2(3):63

Martin JH, Daley JM, Burdg HB (1988) Buying influences and perceptions of transportation services. Ind Mark Manag 17(4):305-314. https://doi.org/10.1016/0019-8501(88)90033-8

Marz N, Warren J (2015) Big data: principles and best practices of scalable realtime data systems. Manning Publications Co., New York

Melnyk SA, Davis EW, Spekman RE, Sandor J (2010) Outcome-driven supply chains. MIT Sloan Manag Rev 51(2):33

Miebach Consulting (2017) Nearshoring als Wettbewerbsvorteil - Steigende Komplexität in der supply chain. Retrieved from Frankfurt am Main. http://www.miebach.com/publications/. Accessed 22 Mar 2019

Mitchell VW (1994) Problems and risks in the purchasing of consultancy services. Serv Ind J 14(3):315

Money RB (2000) Word-of-mouth referral sources for buyers of international corporate financial services. J World Bus 35(3):314-329. https://doi.org/10.1016/s1090-9516(00)00041-9

Mordecai A (2005) Anti-offshoring legislation: the new wave of protectionism-the backlash against foreign outsourcing of American service jobs. Rich J Global L Bus 5:85

Müller M, Stölzle W (2016) Socially responsible supply chains: a distinct avenue for future research? In: Bogaschewsky R, Eßig M, Lasch R, Stölzle W (eds) Supply management research. Springer Gabler, Wiesbaden, pp 121-151. https://doi.org/10.1007/978-3-658-08809-5_6

Murray J, Kotabe M, Westjohn S (2009) Global sourcing strategy and performance of knowledge-intensive business services: a two-stage strategic fit model. J Int Mark 17(4):90-105

Murray A, Skene K, Haynes K (2017) The circular economy: an interdisciplinary exploration of the concept and application in a global context. J Bus Ethics 140(3):369-380

Newton DA (1965) Advertising agency services: make or buy. Harv Bus Rev 43(4):111-118

Nicoletti B (2018) The future: procurement 4.0. In: Agile procurement, pp 189-230. Palgrave Macmillan, Cham. https://doi.org/10.1007/978-3-319-61085-6_8

Nordås HK, Rouzet D, Benz S, Ferenz J, Gonzales F, Grosso MG, Spinelli F (2017) Services trade policies and the global economy. OECD Publishing, Paris. https://doi.org/10.1787/9789264275232-en

Nordin F, Agndal H (2008) Business service sourcing: a literature review and agenda for future research. Int J Integr Supply Manag 4(3/4):378-405

Ojansivu I, Alajoutsijärvi K, Salo J (2013) The development of post-project buyer-seller interaction in service-intensive projects. Ind Mark Manag 42(8):1318-1327

Ostrom AL, Parasuraman A, Bowen DE, Patricio L, Voss CA (2015) Service research priorities in a rapidly changing context. J Serv Res 18(2):127-159 
Oxford Economics (2015) The future of procurement: one survey, two perspectives. Retrieved from www.oxfordeconomics.com. Accessed 22 Mar 2019

Parasuraman A, Zeithaml VA, Berry LL (1985) A conceptual model of service quality and its implications for future research. J Mark 49:41-50

Pasadeos Y, Phelps J, Kim B-H (1998) Disciplinary impact of advertising scholars: temporal comparisons of influential authors, works and research networks. J Advert 27(4):53-70

Pemer F, Sieweke J, Werr A, Birkner S, Mohe M (2014) The cultural embeddedness of professional service purchasing: a comparative study of German and Swedish companies. J Purch Supply Manag 20(4):273-285. https://doi.org/10.1016/j.pursup.2014.05.002

Peng GCA, Nunes MB (2007) Using PEST analysis as a tool for refining and focusing contexts for information systems research. In: Paper presented at the 6th European conference on research methodology for business and management studies, Lisbon, Portugal

Priya Datta P, Roy R (2011) Operations strategy for the effective delivery of integrated industrial product-service offerings: two exploratory defence industry case studies. Int J Oper Prod Manag 31(5):579-603

Provost F, Fawcett T (2013) Data Science for Business: what you need to know about data mining and data-analytic thinking. O'Reilly Media Inc, Newton

Quarshie AM, Salmi A, Leuschner R (2016) Sustainability and corporate social responsibility in supply chains: the state of research in supply chain management and business ethics journals. J Purch Supply Manag 22(2):82-97

Randall WS, Pohlen TL, Hanna JB (2010) Evolving a theory of performance-based logistics using insights from service dominant logic. J Bus Logist 31(2):35-61

Rossignoli C, Ricciardi F (2015) Theories explaining inter-organizational relationships in terms of coordination and control needs. In: Inter-organizational relationships. Springer, Cham, pp 7-36. https:// doi.org/10.1007/978-3-319-11221-3_2

Roth MS, Money RB, Madden TJ (2004) Purchasing processes and characteristics of industrial service buyers in the U.S. and Japan. J World Bus 39(2):183-198. https://doi.org/10.1016/j. jwb.2003.08.008

Russom P (2011) Big data analytics. TDWI best practices report, fourth quarter, vol 19(4), pp 1-34

Sabath R, Whipple JM (2004) Using the customer/product action matrix to enhance internal collaboration. J Bus Logist 25(2):1-19

Schiele JJ (2005) Meaningful involvement of municipal purchasing departments in the procurement of consulting services: case studies from Ontario, Canada. J Purch Supply Manag 11(1):14-27. https ://doi.org/10.1016/j.pursup.2005.04.001

Schiele JJ, McCue CP (2006) Professional service acquisition in public sector procurement: a conceptual model of meaningful involvement. Int J Oper Prod Manag 26(3-4):300-325. https://doi. org/10.1108/014435706106

Schneider L, Wallenburg CM (2013) 50 Years of research on organizing the purchasing function: do we need any more? J Purch Supply Manag 19(3):144-164

Schröter D, Cramer W, Leemans R, Prentice IC, Araújo MB, Arnell NW et al (2005) Ecosystem service supply and vulnerability to global change in Europe. Science 310(5752):1333-1337

Selviaridis K, Norrman A (2014) Performance-based contracting in service supply chains: a service provider risk perspective. Supply Chain Manag Int J 19(2):153-172

Selviaridis K, Wynstra F (2015) Performance-based contracting: a literature review and future research directions. Int J Prod Res 53(12):3505-3540

Selviaridis K, Agndal H, Axelsson B (2011) Business services 'in the making': (de)stabilisation of service definitions during the sourcing process. J Purch Supply Manag 17(2):73-86. https://doi. org/10.1016/j.pursup.2010.08.001

Seuring SA (2003) Outsourcing into service factories: an exploratory analysis of facility operators in the German chemical industry. Int J Oper Prod Manag 23(10):1207-1223

Sheffi Y (2004) Combinatorial auctions in the procurement of transportation services. Interfaces 34(4):245-252. https://doi.org/10.1287/inte.1040.0075

Short J (2009) The art of writing a review article. J Manag 35(6):1312-1317

Smeltzer LR, Ogden JA (2002) Purchasing professionals' perceived differences between purchasing materials and purchasing services. J Supply Chain Manag 38(1):54-70

Spina G, Caniato F, Luzzini D, Ronchi S (2013) Past, present and future trends of purchasing and supply management: an extensive literature review. Ind Mark Manag 42(8):1202-1212 
Stank TP, Paul Dittmann J, Autry CW (2011) The new supply chain agenda: a synopsis and directions for future research. Int J Phys Distrib Logist Manag 41(10):940-955

Stanley LL, Wisner JD (2002) The determinants of service quality: issues for purchasing. Eur J Purch Supply Manag 8(2):97-109. https://doi.org/10.1016/s0969-7012(01)00009-0

Stock JR, Zinszer PH (1987) The industrial purchase decision for professional services. J Bus Res 15(1):1-16. https://doi.org/10.1016/0148-2963(87)90014-2

Stuart FI (1991) Purchasing in an R\&D environment: effective teamwork in busines. J Supply Chain Manag 27(4):29-34

Sumo R, van der Valk W, Duysters G, van Weele A (2016a) Using performance-based contracts to foster innovation in outsourced service delivery. Ind Mark Manag 59:12-24. https://doi.org/10.1016/j. indmarman.2016.05.029

Sumo R, van der Valk W, van Weele A, Bode C (2016b) Fostering incremental and radical innovation through performance-based contracting in buyer-supplier relationships. Int J Oper Prod Manag 36(11):1482-1503

Tranfield D, Denyer D, Smart PT (2003) Towards a methodology for developing evidence-informed management knowledge by means of systematic review. Br J Manag 14:207-222

UN General Assembly (2015) Transforming our world: the 2030 agenda for sustainable development, 21 October 2015, A/RES/70/1. https://www.refworld.org/docid/57b6e3e44.html. Accessed 19 Aug 2019

van der Valk W (2008) Service procurement in manufacturing companies: results of three embedded case studies. Ind Mark Manag 37(3):301-315. https://doi.org/10.1016/j.indmarman.2007.07.007

van der Valk W, Rozemeijer F (2009) Buying business services: towards a structured service purchasing process. J Serv Mark 23(1):3-10. https://doi.org/10.1108/08876040910933048

van der Valk W, Wynstra F (2014) Variety in business-to-business services and buyer-supplier interaction. Int J Oper Prod Manag 34(2):195-220

Van Eck NJ, Waltman L (2010) Software survey: VOSviewer, a computer program for bibliometric mapping. Scientometrics 84(2):523-538

van Mossel H-J, van der Valk W (2008) Securing customer satisfaction through component service specifications. J Purch Supply Manag 14(4):241-252. https://doi.org/10.1016/j.pursup.2008.06.005

van Tulder R (2017) Gettin all the motives right: driving international corporate responsibility (ICR) to the next level, vol 1. The Partnerships Ressoure Center-Erasmus University Rotterdam, Rotterdam

Van Weele AJ (2005) Purchasing and supply chain management: analysis, strategy, planning and practice, 4th edn. Thomson Learning, London

Vandermerwe S, Rada J (1988) Servitization of business: adding value by adding services. Eur Manag J 6(4):314-324

Vargo SL, Lusch RF (2004) Evolving to a new dominant logic for marketing. J Mark 68(1):1-17

Verma T, Renu R, Gaur D (2014) Tokenization and filtering process in RapidMiner. Int J Appl Inf Syst $7(2): 16-18$

Vickrey W (1961) Counterspeculation, auctions, and competitive sealed tenders. J Financ 16(1):8-37

vom Brocke J, Simons A, Riemer K, Niehaves B, Plattfaut R, Cleven A (2015) Standing on the shoulders of giants: challenges and recommendations of literature search in information systems research. CAIS. https://doi.org/10.17705/1CAIS.03709

Voss C, Tsikriktsis N, Frohlich M (2002) Case research in operations management. Int J Oper Prod Manag 22(2):195-219

Webster J, Watson RT (2002) Analyzing the past to prepare for the future: writing a literature review. Manag Inf Syst Q 26(2):13-23

Webster FE Jr, Wind Y (1972) A general model for understanding organizational buying behavior. J Mark 36:12-19

Werr A, Pemer F (2007) Purchasing management consulting services-From management autonomy to purchasing involvement. J Purch Supply Manag 13(2):98-112. https://doi.org/10.1016/j.pursu p.2007.05.003

West DC (1997) Purchasing professional services: the case of advertising agencies. J Supply Chain Manag 33(2):2-9

Williams NR, Denning BP (2009) The new protectionism and the american common market. Notre Dame L Rev 85:247

Williamson OE (1975) Markets and hierarchies: analysis and antitrust implications: a study in the economics of internal organization. Free Press, New York 
Wittreich WJ (1966) How to buy/sell professional services. Harv Bus Rev 44(2):127-138

Wu DD (2008) Between global and local: hybridized appeals in China web auto ads. Corp Commun Int J 13(1):68-79

Wynstra F (2010) What did we do, who did it and did it matter? A review of fifteen volumes of the (European) journal of purchasing and supply management. J Purch Supply Manag 16(4):279-292

Wynstra F, Axelsson B, van der Valk W (2006) An application-based classification to understand buyersupplier interaction in business services. Int J Serv Ind Manag 17(5):474-496

Wynstra F, Rooks G, Snijders C (2018) How is service procurement different from goods procurement? Exploring ex ante costs and ex post problems in IT procurement. J Purch Supply Manag 24(2):83-94

Zhang B, Ding H, Li H, Wang W, Yao T (2013) A sampling-based stochastic winner determination model for truckload service procurement. Netw Spatial Econ 14(2):159-181. https://doi.org/10.1007/ s11067-013-9214-6

Zimmermann S, Muller M, Heinrich B (2016) Exposing and selling the use of web services-an option to be considered in make-or-buy decision-making. Decis Support Syst 89:28-40. https://doi. org/10.1016/j.dss.2016.06.006

Zupic I, Čater T (2015) Bibliometric methods in management and organization. Organ Res Methods 18(3):429-472

Publisher's Note Springer Nature remains neutral with regard to jurisdictional claims in published maps and institutional affiliations. 